\title{
Long-distance electron transport occurs globally in marine sediments
}

\author{
Laurine D. W. Burdorf ${ }^{1}$, Anton Tramper ${ }^{1}$, Dorina Seitaj ${ }^{1,2}$, Lorenz Meire ${ }^{3,4}$, Silvia Hidalgo-Martinez ${ }^{1}$, \\ Eva-Maria Zetsche ${ }^{1,5}$, Henricus T. S. Boschker ${ }^{1}$, and Filip J. R. Meysman ${ }^{1,2}$ \\ ${ }^{1}$ NIOZ Royal Netherlands Institute for Sea Research, Department of Estuarine and Delta Systems, and Utrecht University, \\ Korringaweg 7, 4401 NT Yerseke, the Netherlands \\ ${ }^{2}$ Department of Analytical, Environmental and Geo-Chemistry, Vrije Universiteit Brussel, Pleinlaan 2, \\ 1050 Brussels, Belgium \\ ${ }^{3}$ Greenland Institute of Natural Resources, Greenland Climate Research Centre, P.O. Box 570, Kivioq 5 , \\ 3900 Nuuk, Greenland \\ ${ }^{4}$ Arctic Research Centre, Aarhus University, 8000 Aarhus, Denmark \\ ${ }^{5}$ Department of Marine Sciences, University of Gothenburg, Carl Skottsberg gata 22B, 41319 Gothenburg, Sweden
}

Correspondence to: Laurine D. W. Burdorf (laurine.burdorf@gmail.com)

Received: 29 August 2016 - Discussion started: 13 September 2016

Revised: 28 November 2016 - Accepted: 8 December 2016 - Published: 10 February 2017

\begin{abstract}
Recently, long filamentous bacteria have been reported conducting electrons over centimetre distances in marine sediments. These so-called cable bacteria perform an electrogenic form of sulfur oxidation, whereby long-distance electron transport links sulfide oxidation in deeper sediment horizons to oxygen reduction in the upper millimetres of the sediment. Electrogenic sulfur oxidation exerts a strong impact on the local sediment biogeochemistry, but it is currently unknown how prevalent the process is within the seafloor. Here we provide a state-of-the-art assessment of its global distribution by combining new field observations with previous reports from the literature. This synthesis demonstrates that electrogenic sulfur oxidation, and hence microbial longdistance electron transport, is a widespread phenomenon in the present-day seafloor. The process is found in coastal sediments within different climate zones (off the Netherlands, Greenland, the USA, Australia) and thrives on a range of different coastal habitats (estuaries, salt marshes, mangroves, coastal hypoxic basins, intertidal flats). The combination of a widespread occurrence and a strong local geochemical imprint suggests that electrogenic sulfur oxidation could be an important, and hitherto overlooked, component of the marine cycle of carbon, sulfur and other elements.
\end{abstract}

\section{Introduction}

Recently, a novel type of filamentous bacteria has been discovered (Pfeffer et al., 2012), which is capable of generating and conducting electrical currents over centimetre-scale distances (Nielsen et al., 2010). These so-called "cable bacteria" live within the upper centimetres of the seafloor (Malkin et al., 2014) and form a mono-phyletic group within the Desulfobulbaceae family that currently encompasses six species of filamentous bacteria belonging to two genera, Candidatus Electrothrix and Candidatus Electronema (Trojan et al., 2016). By generating long-distance electron transport, cable bacteria induce a measurable electrical field within the sediment (Risgaard-Petersen et al., 2014, 2015). As a result, the seafloor is no longer an electrically neutral deposit, since some marine sediments are electroactive, which means that both ions and organisms are influenced by electrical fields. This finding has major ramifications for the biogeochemical cycling and microbial ecology of the seafloor (Nielsen and Risgaard-Petersen, 2015; Seitaj et al., 2015). However, as cable bacteria have only been recently discovered, it is presently unknown how prevalent long-distance electron transport is across the seafloor on a global scale. Here, we provide a first assessment of the global distribution of electroactive marine sediments. 
Cable bacteria bypass the traditional redox cascade by linking two spatially segregated redox half-reactions by means of long-distance electron transport (Nielsen et al., 2010; Pfeffer et al., 2012). This way, they induce a previously unknown type of sulfur cycling in marine sediments, which is referred to as electrogenic sulfur oxidation (Meysman et al., 2015). By transferring electrons from cell to cell along the longitudinal axis of their multi-cellular filaments, cable bacteria are able to connect the oxidation of sulfide in the deeper parts of the sediment to the reduction of oxygen in the top millimetres of the sediment. Figure 1 provides a schematic diagram of the metabolism of cable bacteria, which involves both anodic sulfide oxidation by cells located in deeper anoxic layers and cathodic oxygen reduction by cells located in the oxic zone of the sediment.

Electrogenic sulfur oxidation (e-SOx) has a large impact on the geochemistry of the sediment, because the process is responsible for a large part of the oxygen and sulfide consumption in the sediment (Nielsen et al., 2010). At the same time, e-SOx induces large excursions in the porewater $\mathrm{pH}$ (Nielsen et al., 2010; Meysman et al., 2015). Alkaline conditions $(\mathrm{pH}>8.5)$ are generated in the oxic layer as a result of proton consumption during cathodic oxygen reduction, while acidic conditions $(\mathrm{pH}<6.5)$ are created in deeper anoxic layers due to proton production during anodic sulfide oxidation (Fig. 1). Through their impact on the porewater $\mathrm{pH}$, cable bacteria induce a range of secondary reactions and thus stimulate the geochemical cycling of a range of elements including iron, manganese and calcium (Rao et al., 2016b; Risgaard-Petersen et al., 2012). The low pH in the deeper layers of the sediment induces dissolution of iron sulfides and calcium carbonates, which subsequently causes the diffusion of iron and calcium cations to the oxic layer, where iron oxides form and carbonates re-precipitate to form a rigid mineral crust on top of the sediment (Risgaard-Petersen et al., 2012). This stimulation of the mineral cycling by e-SOx also induces high effluxes of calcium and alkalinity from the sediment (Rao et al., 2016b).

Recent evidence indicates that the influence of cable bacteria may extend well beyond the sediment and impact the water column chemistry (Seitaj et al., 2015; Sulu-Gambari et al., 2016a). In particular, cable bacteria influence the ecosystem functioning of seasonal hypoxic environments through the regulation of the phosphorus cycle (Sulu-Gambari et al., 2016a), manganese cycle (Sulu-Gambari et al., 2016b) and iron cycle (Seitaj et al., 2015). More specifically, it has been proposed that cable bacteria induce the formation of a large pool of sedimentary iron (hydr)oxides in spring, which then acts as a firewall against the development of the sulfidic water conditions in summer (Seitaj et al., 2015). This way, cable bacteria appear capable of influencing the elemental cycling and ecosystem functioning of coastal systems at basin scales.

The large impact of cable bacteria on the geochemistry and microbial ecology of marine sediments raises the question of how prevalent and dominant these bacteria are on a global

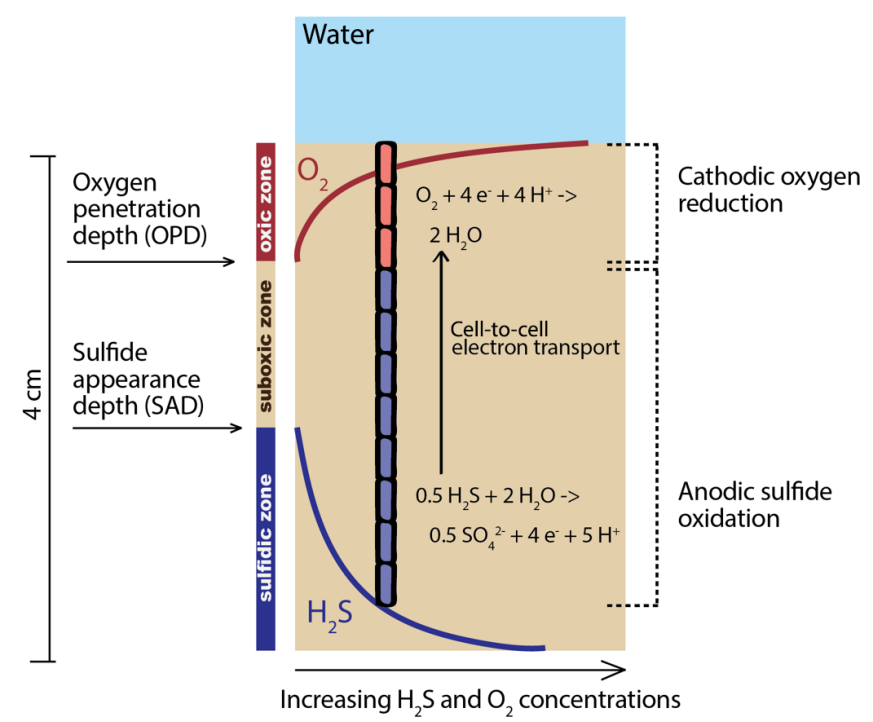

Figure 1. Schematic illustration of the metabolism of a cable bacterium. Electrogenic sulfur oxidation involves two spatially separated redox half reactions, which are referred to as the cathodic oxygen reduction and the anodic sulfide oxidation. The redox coupling is ensured by an electron transport axis through the cable bacteria filament. The metabolism of cable bacteria leads to three distinct geochemical zones in the sediment: the oxic zone delineated by the sediment-water interface and the oxygen penetration depth (OPD); the suboxic zone defined as the sediment zone, where neither $\mathrm{O}_{2}$ nor $\mathrm{H}_{2} \mathrm{~S}$ is detectable, and the sulfidic zone, where free sulfide accumulates below the sulfide appearance depth (SAD).

scale. Until now, cable bacteria have only been reported from a restricted number of coastal sites and habitats. The geochemical fingerprint of e-SOx (Nielsen et al., 2010) and also the cable bacteria themselves (Pfeffer et al., 2012) were originally discovered in a laboratory enrichment experiment using sediment from the Baltic Sea (Aarhus Bay, Denmark). Subsequently, the geochemical fingerprint, together with high densities of cable bacteria, were recorded under natural conditions at three different sites in the southern North Sea, including a salt marsh, a seasonally hypoxic basin and a coastal mud accumulation site (Malkin et al., 2014). Since then, laboratory enrichments have revealed the growth of cable bacteria in sediments from salt marshes on the Atlantic coast of North America (Larsen et al., 2015; Rao et al., 2016b), while a multi-year study has shown the seasonal reappearance of intense cable bacteria activity in Lake Grevelingen, a seasonally hypoxic basin in the Netherlands (Seitaj et al., 2015; Sulu-Gambari et al., 2016a). Just recently, the presence and activity of cable bacteria was demonstrated in temperate mangroves in Australia (Burdorf et al., 2016).

There are, however, indications that the activity of cable bacteria is more widespread in the seafloor than currently documented. A re-evaluation of published porewater data in combination with an examination of 16S rRNA archives (Malkin et al., 2014) suggests a far broader natural distribu- 
tion, indicating that long-distance transport could be prominent in other marine habitats (e.g. bivalve beds, mid-oceanic ridges, the deep sea). The goal of this study is to provide a first synthesis of the global distribution of cable bacteria in seafloor sediments, reviewing the data that are already published in combination with an extensive set of new observations. This analysis suggests that e-SOx is a far more important component of the sedimentary sulfur cycle in the seafloor than previously recognized.

\section{Material and methods}

\subsection{Screening procedures}

The impact of cable bacteria on marine sediments can be assessed in two ways: (1) by demonstrating that cable bacteria are present at high abundances in the sediment, or (2) by demonstrating the metabolic activity of the cable bacteria, i.e. by revealing the impact of e-SOx on the sediment geochemistry. The verification of the presence of cable bacteria and the subsequent quantification of their abundance are performed by microscopic and molecular techniques (Fig. 2; right column). Alternatively, the demonstration of metabolic activity of cable bacteria is achieved by the analysis of porewater geochemistry and/or a direct measurement of the electrical potential that is generated in the sediment in association with e-SOx (Fig. 2; left column). These techniques are reviewed in more detail below. Clearly, the detection of metabolic activity implies presence, though it is not the case the other way around. Low cable bacteria abundances can be detected without noticing an impact on the sediment geochemistry. Consequently, the direct demonstration of eSOx activity provides stronger evidence for the geochemical impact of cable bacteria on the seafloor than their presence alone. However, as we will show below, high densities of cable bacteria are typically tightly correlated with high metabolic activity, and so the investigation of cable bacteria abundance remains a useful indicator.

Up to now, the presence/activity of cable bacteria in natural sediment environments has been demonstrated in two principal ways: (1) the phenomenon is directly demonstrated under field conditions (Malkin et al., 2014), or (2) it is demonstrated by means of a laboratory induction experiment (Schauer et al., 2014; Larsen et al., 2015). In a laboratory induction, sediment is retrieved from the field, homogenized and mixed, and the activity and/or presence of cable bacteria is evaluated during the incubation period (days to weeks). Such laboratory incubations can be used as a simple, quick and inexpensive screening method, since direct field observations are typically more challenging and logistically complex. However, prolific growth and strong activity of cable bacteria in laboratory induction experiments do not unequivocally prove that the process also occurs at the field site from where the incubated sediment has been retrieved. Therefore,

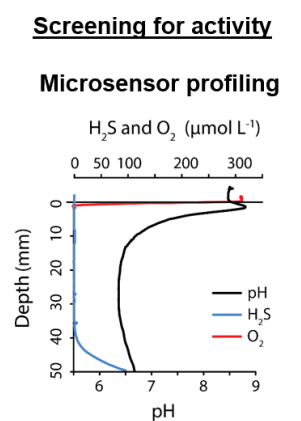

Electrical potential profiling

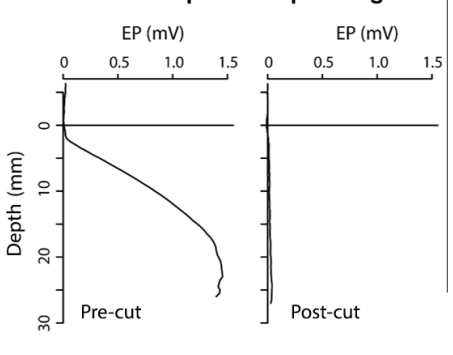

$\underline{\text { Screening for presence }}$

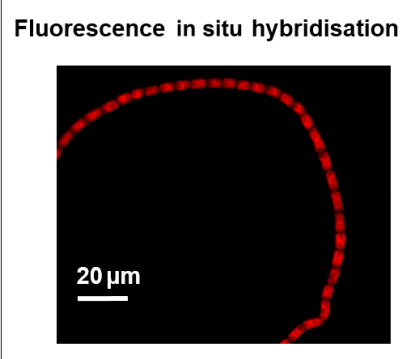

Electron microscopy

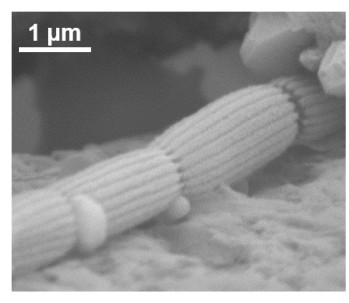

Figure 2. Overview of the methods that demonstrate cable bacteria activity (left column) and cable bacteria presence (right column) in aquatic sediments. Microsensor profiling produces highresolution depth profiles of $\mathrm{pH}, \mathrm{H}_{2} \mathrm{~S}$ and $\mathrm{O}_{2}$, which reveal the characteristic geochemical fingerprint of electrogenic sulfur oxidation ( $\mathrm{pH}$ excursions and suboxic zone). Electrical potential profiling directly demonstrates the build-up of the electrical potential in the sediment due to long-distance electron transport (Damgaard et al., 2015; Risgaard-Petersen et al., 2015). Passing a thin wire through the sediment cuts the cable bacteria filaments and confirms that the observed build-up of the electrical potential is due to cable bacteria activity. The presence of cable bacteria can be confirmed by RNA staining (FISH probe DSB706) or by electron microscopy, which reveals the parallel ridges on the cell envelope that are unique to cable bacteria.

the results of a laboratory induction procedure have a potential character, while the field assessment procedure provides direct evidence for the natural impact of cable bacteria. However, as we will show below, there is a strong correlation between success in laboratory induction and natural occurrence, which suggests that laboratory induction provides useful - albeit indicative - information on the natural distribution of cable bacteria.

In this study, we have compiled previously published data on the distribution of cable bacteria in seafloor sediments. Additionally, we have extended this data set by assessing the presence and/or activity of cable bacteria in a number of geographical locations during various sampling campaigns conducted between 2011 and 2016. In addition to the global geographical distribution, we examine the aspect of habitat diversity within the same geographical region. To this end, we have performed a detailed investigation of different coastal habitats (e.g. salt marshes, mud flats, bivalve reefs) within a restricted region in the southern North Sea. In these surveys, we combined different screening procedures (Fig. 2), assess- 
ing the presence and/or activity under laboratory and/or field conditions.

\subsection{Field sampling}

Metabolic activity in the field can be detected either by in situ microsensor profiling (e.g. Risgaard-Petersen et al., 2015), or by the retrieval of sediment cores and immediate inspection by microsensor profiling, either shipboard or in the laboratory (e.g. Malkin et al., 2014). Here we only employed the latter technique. Sediment cores from shallow, intertidal sites were collected at low tide by manual insertion of plastic core liners (different types were used at different locations; inner diameter range 36-60 mm). Cores from subtidal sites were retrieved using a gravity core sampler $(60 \mathrm{~mm}$ internal diameter; UWITEC (Austria) or Kajak sampler, KC Denmark $\mathrm{A} / \mathrm{S})$. The time between sampling and measurement was kept as short as possible, and sediment core analysis (microsensor depth profiling or core sectioning for microscopy) was always performed within $12 \mathrm{~h}$ of core sampling. During this period, the overlying water of the subtidal sediment cores was kept oxygenated by air bubbling or by submerging the sediment cores into a large water bath filled with in situ bottom water. Shipboard analysis within $12 \mathrm{~h}$ of core sampling appears sufficiently rapid to detect the in situ signal. In laboratory induction experiments, cable bacteria populations typically require 5 to 14 days before the characteristic e-SOx signal is detected by microsensor profiling (Pfeffer et al., 2012; Schauer et al., 2014; Rao et al., 2016b). While we observed that core disturbance can eliminate the characteristic e-SOx fingerprint (i.e. false negatives are possible), the shipboard detection of e-SOx activity within a period of hours provides a positive confirmation that the activity was also present in situ (i.e. false positives are excluded, as e-SOx activity in laboratory conditions takes $>5$ days to develop). Retrieved sediment cores were always visually inspected prior to analysis and only cores with a visually undisturbed sediment-water interface were retained for analysis (potential exclusion of false negatives).

\subsection{Laboratory induction experiments}

As noted above, laboratory induction of cable bacteria growth provides an inexpensive and indicative screening method. Here, laboratory inductions were carried out in a fashion similar to previous studies (Pfeffer et al., 2012; Vasquez-Cardenas et al., 2015). To remove large burrowing macrofauna, the sediment was either sieved over a $0.5-1 \mathrm{~mm}$ sieve (Nielsen et al., 2010; Malkin and Meysman, 2015) or sediment cores were left undisturbed and sealed for a longer period of time to asphyxiate the benthos (Rao et al., 2014, $2016 \mathrm{~b}$ ). The exclusion of burrowing macrofauna is thought to prevent the mechanical disturbance of the cable bacteria filament network (Malkin et al., 2014) and allows for an assessment of the impact of cable bacteria on the sediment geochemistry without the effect of bioturbation. Asphyxiated sediment cores were used as such (i.e. no homogenization). Sieved sediments were homogenized and packed into plastic core liners (inner diameter $36 \mathrm{~mm}$ ), adjusting the height of the sediment to the rim of the core liner (for ease of microsensor profiling). At the start of the laboratory incubation, sediment cores were submerged in an aquarium in a temperaturecontrolled climate room fixed at in situ temperature where possible. During laboratory inductions, the overlying water of the aquarium was continuously bubbled with ambient air to retain a fully oxygenated water column.

\subsection{Geochemical microsensor profiling}

The metabolic activity of cable bacteria imposes a distinct geochemical fingerprint on the porewater, which is revealed by a combination of oxygen $\left(\mathrm{O}_{2}\right)$, free sulfide $\left(\mathrm{H}_{2} \mathrm{~S}\right)$ and $\mathrm{pH}$ microsensor profiling (Nielsen et al., 2010; Meysman et al., 2015). The first characteristic feature is the presence of a wide suboxic zone (here: $\left[\mathrm{H}_{2} \mathrm{~S}\right]$ and $\left[\mathrm{O}_{2}\right]<1 \mu \mathrm{mol} \mathrm{L}{ }^{-1}$ ). The depth of the suboxic zone is a good indication of the depth to which the cable bacteria network is present (Schauer et al., 2014). Secondly, the spatial segregation of the two redox half-reactions leads to a distinct $\mathrm{pH}$ signature in the sediment porewater (Fig. 1; Meysman et al., 2015). The anodic oxidation of sulfide at depth causes proton production, while conversely, the cathodic reduction of oxygen and/or nitrate in the top sediment leads to strong proton consumption. This results in a distinctive $\mathrm{pH}$ depth profile, with a subsurface $\mathrm{pH}$ maximum at the oxygen penetration depth (OPD) and a $\mathrm{pH}$ minimum near the sulfide appearance depth (SAD). The amplitude of the excursions in the $\mathrm{pH}$ profile is the combined result of the sediment buffering capacity and cable bacteria activity. The $\mathrm{pH}$ excursion, $\Delta \mathrm{pH}$, defined as the maximum $\mathrm{pH}$ in the oxic zone minus the minimum $\mathrm{pH}$ in the suboxic zone, can be used as a simple indicator to compare cable bacteria activity across sites (assuming that sediment buffering capacity is similar).

In this study, microsensor depth profiles of $\mathrm{O}_{2}, \mathrm{pH}$ and $\mathrm{H}_{2} \mathrm{~S}$ were recorded using commercial microelectrodes (Unisense A.S. Denmark, tip sizes pH: $200 \mu \mathrm{m}, \mathrm{H}_{2} \mathrm{~S}$ : $100 \mu \mathrm{m}$, $\left.\mathrm{O}_{2}: 50 \mu \mathrm{m}\right)$ operated with a motorized micromanipulator (Unisense A. S., Denmark). Oxygen profiles were measured separately at 50 or $100 \mu \mathrm{m}$ resolution, while $\mathrm{pH}$ and $\mathrm{H}_{2} \mathrm{~S}$ were conjointly recorded with a $200 \mu \mathrm{m}$ resolution in the oxic zone of the sediment, and increasing step size in the deeper layers of the sediments. The sensors were calibrated by following standard calibration procedures as described previously (Malkin et al., 2014) $\left(\mathrm{H}_{2} \mathrm{~S}: 3\right.$ to 5 point standard curve using $\mathrm{Na}_{2} \mathrm{~S}$ standards; $\mathrm{O}_{2}: 2$ point calibration using $100 \%$ in air bubbled seawater and the anoxic zone of the sediment; pH: 3 NBS standards $(4,7,10)$ and TRIS buffer). The $\mathrm{pH}$ data are reported on the total $\mathrm{pH}$ scale and $\mathrm{\Sigma H}_{2} \mathrm{~S}$ was calculated from $\mathrm{H}_{2} \mathrm{~S}$ based on the $\mathrm{pH}$ measured at the same depth. 


\subsection{Electrical potential profiling}

Cable bacteria impose an electron transport from the anodic cells in the anoxic zone to cathodic cells in the oxic zone (Fig. 1), which results in a countercurrent of equal magnitude in the pore water. Due to a difference in mobility between negative and positive ions in the porewater, this ionic countercurrent creates a measurable difference in electrical potential (EP) between the surface and deeper sediment (Revil et al., 2010), which is in the range of $0.5-2 \mathrm{mV}$ in marine sediments (Risgaard-Petersen et al., 2014, 2015). This electrical potential should not be confused with the redox potential, which expresses the tendency of a solution to take up or release electrons by redox reactions (Damgaard et al., 2014). While a gradient in redox potential is present in all coastal sediments and reflects the downcore variation in the oxidation state of the pore water, an EP gradient is only present in sediments showing either salinity gradients (potentials induced by ion diffusion) or sediment showing cable activity (potentials induced by long-distance electron transport). The EP depth profile can be recorded at high resolution by a newly developed EP microsensor (Damgaard et al., 2014) and thus provides - in the absence of salinity gradients - a direct confirmation of the metabolic activity of cable bacteria (Risgaard-Petersen et al., 2014). The current density generated by the cable bacteria can be derived from the electrical potential measurement using Ohms Law, $J=\sigma E$, where $J$ is the flux of electrons (current density), $E$ is the electrical field and $\sigma$ the electrical conductivity of the sediment. The electrical field can be derived from the EP depth profile, either using the voltage difference between the SWI and the SAD (Risgaard-Petersen et al., 2014) or as the slope of the EP profile at the oxic-anoxic transition (Damgaard et al., 2014). The conductivity $\sigma$ of the porewater is obtained from the porewater salinity relationship using the equations by Fofonoff and Millard (1983), as implemented in the $\mathrm{R}$ package marelac (Soetaert et al., 2010, available from http://cran.r-project.org), and is corrected for tortuosity similar to the diffusion coefficient (Damgaard et al., 2014).

Here, we employed EP microsensors built according to (and provided by) Damgaard et al. (2014). These custombuilt EP sensors were connected in conjunction with a standard reference electrode (Radiometer, Denmark) to a of high-impedance voltmeter (instrument type MB $11 \mathrm{mV}$, Microscale Measurement, The Hague, the Netherlands). Signal noise was repressed using additional capacitors (total: $470 \mathrm{nF}$ ) connected to the voltmeter, and the analogue output of the voltmeter was converted using a 16 bit A/D converter (Unisense, Denmark). The signal drift was estimated at $\pm 0.06 \mathrm{mV}$ per depth profile (between the bottom and top sediments). To counter signal drift, the depth profiles were recorded in two directions: from the sediment-water interface down to deeper layers and, subsequently, in the reverse direction. From these two EP profiles, an average depth profile was calculated. The salinity of the overlying water was set to match the salinity of the porewater in order to avoid the creation of diffusion potentials, which could be mistakenly interpreted as arising from long-distance electron transport.

\subsection{Bright-field and scanning electron microscopy}

Conventional bright-field microscopy can be used as a first indication of the presence of cable bacteria in the sediment. Cable bacteria can be recognized as thin (approx. 0.5-5 $\mu \mathrm{m}$ width), long (up to $>1 \mathrm{~cm}$ ) threads, often arranged in clumps and sticking to sediment particles. Although informative, bright-field microscopy cannot provide unambiguous confirmation that the observed filaments are indeed cable bacteria. This is because various other filamentous bacteria (e.g. cyanobacteria), filamentous fungi or plant detritus can also be present as long, thin threads in the sediment (GodinhoOrlandi and Jones, 1981). However, scanning or transmission electron microscopy does allow positive identification of cable bacteria. This is because cable bacteria display a unique surface topology, which shows distinctive ridges that run in parallel along the longitudinal axis of the filaments (Pfeffer et al., 2012; Malkin et al., 2014). Until now, all cable bacteria detected by FISH probes (see Sect. 2.7) also display these characteristic ridges, and so the ridge pattern appears unique to cable bacteria (Fig. 2). Deposition of minerals onto the surface of the cable bacteria can sometimes mask the ridge pattern. Such mineral encrustation is frequently observed in the oxic zone of the sediment, likely resulting from $\mathrm{FeOOH}$ deposition through ferrous iron oxidation. Here, scanning electron microscopy (SEM) was performed using a Phenom Pro desktop microscope (Phenom-World B. V., the Netherlands) with a beam intensity of $10 \mathrm{kEV}$. Typically, a small drop of sediment was dispersed on a suitable carrier (aluminium stub coated with a carbon adhesive pad) and subsequently airdried. Sometimes, cable bacteria were also picked out of the sediment as clumps. For this purpose Pasteur pipettes tips were carefully elongated using a flame and the very tip bent into a U-shape, to create a sort of fishing hook. Before imaging, the sample was gold-coated for $30 \mathrm{~s}$, providing a $\sim 5 \mathrm{~nm}$ thick gold layer (Polaron E5100 sputter coater, Van Loenen Instruments, Belgium).

\subsection{Fluorescence in situ hybridization}

Fluorescence in situ hybridization (FISH) is a molecular staining technique which targets specific regions of the ribosomal RNA. Once a probe successfully hybridizes with its target rRNA region, a fluorescent signal is emitted that can be visualized with epifluorescence microscopy. Probes can be designed to target different phylogenetic levels, ranging from broad groups (e.g. EUB mix, targeting $~ 90 \%$ of bacteria) to specific taxa. In previous studies, the probe DSB706 (Manz et al., 1992), which targets most Desulfobulbaceae as well as Thermodesulforhabdus, has been shown to success- 
fully hybridize with cable bacteria (e.g. Pfeffer et al., 2012; Schauer et al., 2014; Seitaj et al., 2015). Here, we performed a standard FISH analysis with the DSB706 probe, following the protocol described in Schauer et al. (2014). For this, 0.5 $\mathrm{mL}$ of sediment was preserved in $96 \%$ ethanol and stored at $-20^{\circ} \mathrm{C}$. Subsamples of $100 \mu \mathrm{l}$ were transferred in $500 \mu \mathrm{L}$ of a $1: 1$ mixture of PBS/ethanol and, subsequently, $10 \mu \mathrm{L}$ of this mixture was filtered through a polycarbonate membrane filter (type GTTP, pore size $0.2 \mu \mathrm{m}$, Millipore, USA). Probe hybridization was performed according to previously published protocols (Pernthaler et al., 2001, 2002).

\section{Results}

\subsection{Proof of concept: laboratory inductions compared to field measurements}

Laboratory incubations of sediments have previously been used as a simple and fast screening technique for potential cable bacteria activity (e.g. Larsen et al., 2015; Burdorf et al., 2016). Previous studies have shown that geochemical fingerprints obtained during laboratory induction are comparable to those obtained from direct field observations (e.g. Seitaj et al., 2015; Rao et al., 2016b). However, in these studies, the sediment was never collected at exactly the same time and place. Here, we performed a direct comparison between laboratory inductions and field measurements. In this methodological test, we compared the geochemical as well as the electrical fingerprints. Intertidal sediment was collected at low tide on 9 October 2014 near an oyster reef on the barrier island of Texel (Wadden Sea, the Netherlands). Sediment for laboratory induction was collected by scooping the first 10$15 \mathrm{~cm}$ of surface sediment into a container. Subsequently, intact sediment cores $(n=2)$ were collected nearby (at approx. $1 \mathrm{~m}$ distance). These field cores were immediately transferred to a nearby laboratory ( $\sim 30 \mathrm{~min}, \mathrm{NIOZ} \mathrm{Texel)}$ and put in an air-bubbled aquarium filled with seawater collected from the sampling site. Within $6 \mathrm{~h}$ after sampling, $\mathrm{pH}, \mathrm{H}_{2} \mathrm{~S}, \mathrm{O}_{2}$ and $\mathrm{EP}$ depth profiles were recorded within the intact sediment cores ( 2 replicate profiles per core). The sediment for laboratory induction was sieved and homogenized upon arrival in the laboratory and kept in an anoxic jar for 2 weeks after which the laboratory induction experiment was started ( 2 replicate cores) with freshly prepared artificial seawater. After 19 days of incubation, $\mathrm{pH}, \mathrm{H}_{2} \mathrm{~S}, \mathrm{O}_{2}$ and $\mathrm{EP}$ depth profiles were also recorded in the incubated cores ( 2 depth profiles for each sensor per core).

Figure 3 shows representative depth profiles recorded during the laboratory induction (right panel) and the corresponding field observations (left panel). Both cores showed a shallow oxygen penetration depth (resp. $0.4 \pm 0.06 \mathrm{~mm}$ in the field vs. $1.2 \pm 0.1 \mathrm{~mm}$ in the laboratory induction) and a clear acidification of the suboxic zone $(\Delta \mathrm{pH}=2.1 \pm 0.4$ in the field vs. $\Delta \mathrm{pH}=2.4 \pm 0.1$ in the laboratory induc-
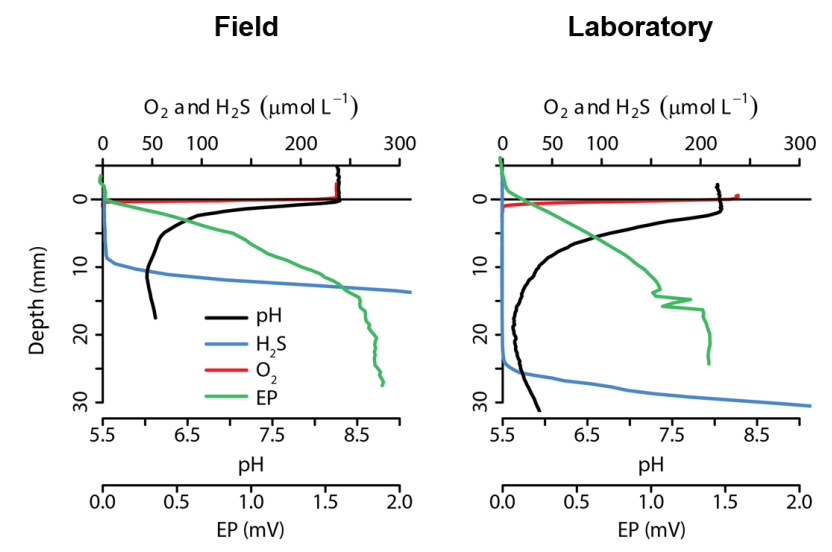

Figure 3. High-resolution depth profiles reveal the typical fingerprint of cable bacteria activity in sediments near a bivalve reef (Cocksdorp, the Netherlands). Left panel: field measurements on intact sediment cores. Profiles were recorded within $3 \mathrm{~h}$ of core collection. Right panel: incubation of sediment from the same location under laboratory conditions. Sediment was sieved and homogenized before incubation. Profiles were recorded after 19 days.

tion). The suboxic zone is wider in the laboratory induction $(20 \pm 3.2 \mathrm{~mm})$ compared to the field measurement $(9 \pm 3.2 \mathrm{~mm})$. The expected $\mathrm{pH}$ maximum in the oxic zone was only detectable in the laboratory induction. This aligns with other recent field observations, which all report e-SOx activity and high abundances of cable bacteria, but no clear pH maximum (Seitaj et al., 2015; Burdorf et al., 2016; van de Velde et al., 2016). The reasons for the absence of the $\mathrm{pH}$ maximum are discussed in detail in Burdorf et al. (2016). The EP depth profile has a similar shape in both cases and the overall increase in EP from the sediment oxic zone to the anoxic zone is also similar $(1.4 \mathrm{mV}$ increase in the laboratory incubation and $1.6 \mathrm{mV}$ for the field measurement). The associated current densities are higher in the field cores $\left(412 \mathrm{~mA} \mathrm{~m}^{-2}\right.$ at salinity 30 and $\left.12^{\circ} \mathrm{C}\right)$ than in the laboratory induction $\left(280 \mathrm{~mA} \mathrm{~m}^{-2}\right.$ at salinity 28 and $\left.18^{\circ} \mathrm{C}\right)$. This points towards a more active cable bacteria population in the field cores. Overall, however, the laboratory induction and field observations provided similar geochemical and electrical fingerprints.

\subsection{Regional habitat diversity of cable bacteria}

To assess the distribution of cable bacteria on a regional scale, we visited 15 sites within the Dutch Wadden Sea and the Rhine-Meuse-Scheldt delta area (North Sea coast of the Netherlands and Belgium; Fig. 4). These 15 sites were visited during different sampling campaigns over the years 20122015 (summarized in Table 1, full details in Table S1 in the Supplement). All data reported here are field observations. It should be noted that the sites investigated are not ecologically homogeneous, in the sense that one site may consist of more than one habitat (e.g. a site may combine a bivalve reef 
Table 1. Summary of the global sample sites where cable bacteria activity was measured or presence of cable bacteria was demonstrated. Full details of all locations are given in Table S1.

\begin{tabular}{|c|c|c|c|c|c|c|c|c|}
\hline \multirow[t]{2}{*}{ Site name } & \multirow[t]{2}{*}{$\begin{array}{r}\text { Sampling } \\
\text { year(s) }\end{array}$} & \multirow[t]{2}{*}{$\begin{array}{r}\text { No } \\
\text { locations }\end{array}$} & \multirow[t]{2}{*}{ Country } & \multirow[t]{2}{*}{ Habitat type } & \multicolumn{2}{|c|}{$\begin{array}{l}\text { Activity } \\
\text { evidence }\end{array}$} & \multicolumn{2}{|c|}{$\begin{array}{l}\text { Presence } \\
\text { evidence }\end{array}$} \\
\hline & & & & & Field & Lab & Field & $\mathrm{Lab}$ \\
\hline Grevelingen & 2012-2015 & 9 & Netherlands & Seasonally hypoxic lake & $\mathrm{X}$ & $\mathrm{X}$ & $\mathrm{X}$ & $\mathrm{X}$ \\
\hline Kobbefjord & 2011 & 1 & Greenland & Fjord sediment & & $\mathrm{X}$ & & \\
\hline Yarra River & 2014 & 1 & Australia & Seasonally hypoxic estuary & $\mathrm{X}$ & $\mathrm{X}$ & $\mathrm{X}$ & $\mathrm{X}$ \\
\hline Long Island Sound & 2013 & 1 & United States & Seasonally hypoxic basin & & $\mathrm{X}$ & & $\mathrm{X}$ \\
\hline Urbino lagoon & 2015 & 1 & Corsica, France & Fringe of seagrass bed & & $\mathrm{X}$ & & $\mathrm{X}$ \\
\hline Sabkhet Arina & 2015 & 1 & Tunisia & Salt flat & & $\mathrm{X}$ & & $\mathrm{X}$ \\
\hline Station 130 & 2015 & 1 & Belgium & Subtidal mud flat & $\mathrm{X}$ & $\mathrm{X}$ & $\mathrm{X}$ & $\mathrm{X}$ \\
\hline \multirow{3}{*}{ Mokbaai } & 2014-2015 & 5 & Netherlands & Oyster reef & $\mathrm{X}$ & $\mathrm{X}$ & & $\mathrm{X}$ \\
\hline & & & & Salt marsh & $\mathrm{X}$ & $\mathrm{X}$ & & $\mathrm{X}$ \\
\hline & & & & Cockle reef & $\mathrm{X}$ & & & \\
\hline Cocksdorp & 2014-2015 & 3 & Netherlands & Oyster/Mussel reef & $\mathrm{X}$ & $\mathrm{X}$ & $\mathrm{X}$ & $\mathrm{X}$ \\
\hline \multirow[t]{3}{*}{ Eastern Scheldt } & 2012-2016 & 8 & Netherlands & Salt marsh & $\mathrm{X}$ & $\mathrm{X}$ & $\mathrm{X}$ & $\mathrm{X}$ \\
\hline & & & & Intertidal mud flats & $X$ & $X$ & $\mathrm{X}$ & $\mathrm{X}$ \\
\hline & & & & Bioturbated sand flat & & $\mathrm{X}$ & & $\mathrm{X}$ \\
\hline Western Scheldt & 2013 & 1 & $\begin{array}{l}\text { Netherlands/ } \\
\text { Belgium }\end{array}$ & Oxygenated estuary & $\mathrm{X}$ & & & \\
\hline
\end{tabular}
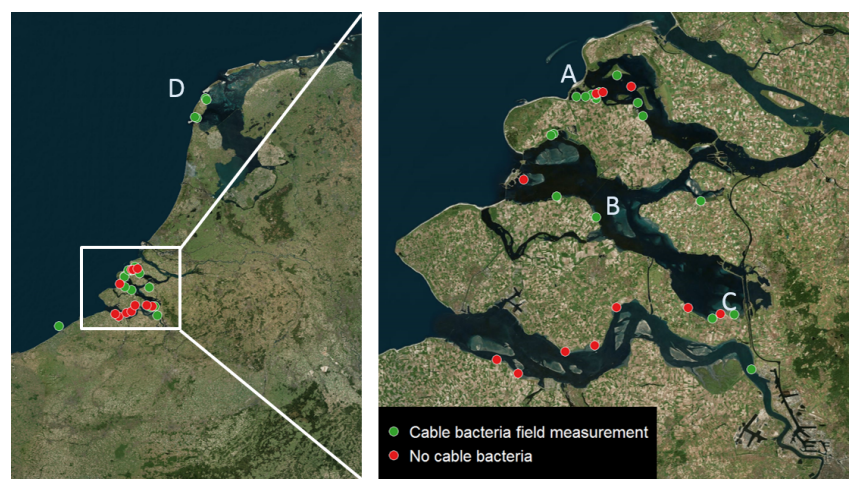

Figure 4. Field site locations examined for cable bacteria activity within a close range to the home laboratory (Belgium and the Netherlands). Green markers indicate locations where cable bacteria activity was found. Red markers indicate locations where cable bacteria activity was not detected. The letters A-D indicate the locations of the sites detailed in Fig. 5.

and its surrounding mud flat). Therefore, each sampling point is called a "location", whereas the term "site" is reserved for a geographically distinct area. Overall, we sampled a total of 28 locations distributed over 15 sites.

\subsubsection{Rhine-Meuse-Scheldt delta}

The sites in the Rhine-Meuse-Scheldt delta were located within a geographically restricted area (all within $100 \mathrm{~km}$ ), but covered a diverse range of coastal habitats (Fig. 4b). We surveyed sediments in three water bodies within the RhineMeuse-Scheldt delta, which each have a distinct ecology and hydrodynamics regime: (1) Lake Grevelingen, (2) the Eastern Scheldt and (3) the Western Scheldt. Lake Grevelingen (1) is an enclosed marine basin in the northern arm of the former Rhine-Meuse-Scheldt estuary. Saline conditions (29-32) are permanently maintained by the small exchange of water with the North Sea through a sluice connection. Seasonal oxygen depletion is a yearly occurring phenomenon in the deeper basins of Lake Grevelingen (i.e. the former estuarine channels). This oxygen depletion typically affects the bottom waters below $15 \mathrm{~m}$, which represent about $6 \%$ of the basin area (Westeijn, 2011). An elaborate sampling campaign, involving monthly water column and sediment sampling, has recently described in detail the temporal response of the sediment geochemistry to seasonal oxygen depletion, revealing the important role of the cable bacteria population dynamics (Seitaj et al., 2015; Sulu-Gambari et al., 2016a). However, these studies all focused on a single station in the Den Osse basin at $34 \mathrm{~m}$ water depth.

In this study, however, we examined the broader spatial distribution of cable bacteria within the sediments of Lake Grevelingen. To this end, we surveyed the depth zone affected by hypoxia (water depths ranging from 12 to $45 \mathrm{~m}$ ) during two seasons (March and November 2015). Sampling locations were distributed over four separate basins in Lake Grevelingen along the former main estuarine channel (Tables 1 and S1). All sampled sites were muddy sediment with a high porosity $(>0.8)$ and with no or only few small bioturbating fauna. All sites experienced bottom water oxygen depletion over the summer. The four locations examined in March 2015 all revealed the distinctive geochemical fingerprint of e-SOx, indicating metabolic activity of cable bacteria 


\section{Site}

(a) Seasonally hypoxic lake

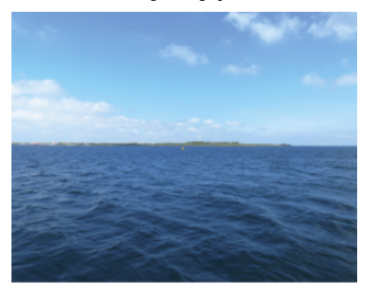

(b) Bivalve reef

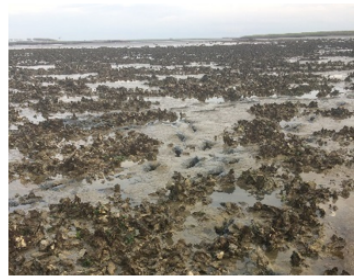

(c) Salt marsh

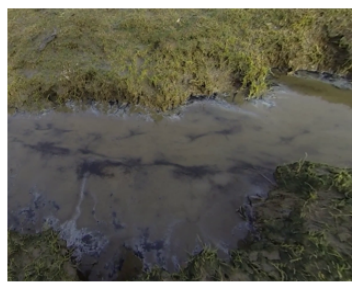

(d) Intertidal mud flat

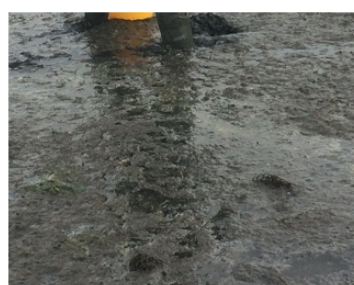

Activity

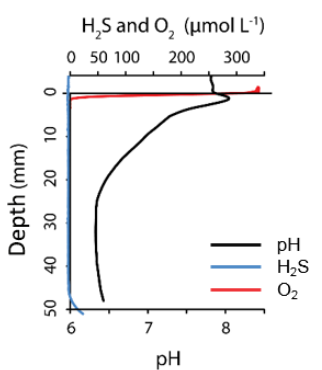

$\mathrm{H}_{2} \mathrm{~S}$ and $\mathrm{O}_{2}\left(\mu \mathrm{mol} \mathrm{L} \mathrm{L}^{-1}\right)$
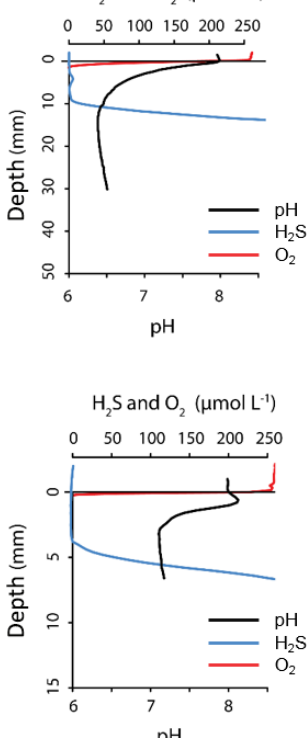

$\mathrm{pH}$

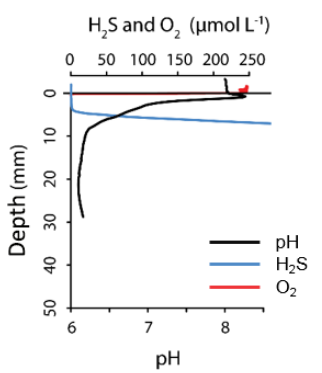

Presence
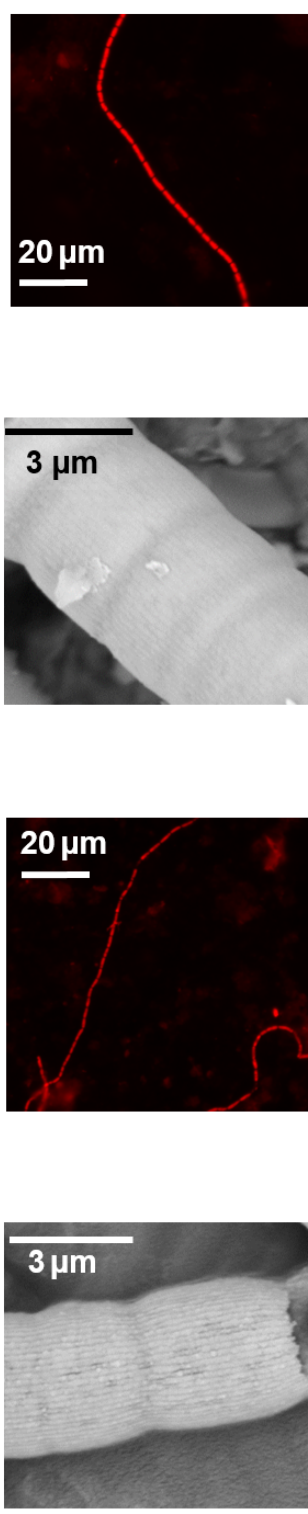

Figure 5. Results from four marine habitats in the Netherlands exemplifying detected cable bacteria activity and presence: (a) sediments in deeper $(>15 \mathrm{~m})$ basins of the seasonally hypoxic Lake Grevelingen, (b) a bivalve reef in the Eastern Scheldt, (c) a salt marsh in the Eastern Scheldt (Rattekaai) and (d) an intertidal mud flat in the Wadden Sea (Mokbaai). Locations are marked by letters A-D in Fig. 4. Left column: photographs of the sampling locations. Middle column: microsensor profiles documenting the geochemical fingerprint of cable bacteria activity. Right column: the presence of cable bacteria was confirmed using microscopy techniques (either by fluorescence in situ hybridization (a, c) or scanning electron microscopy (b, d). Full-size SEM images are available in the Supplement (Fig. S2.1-2.2).

(Fig. 5). A wide suboxic zone was observed in all stations $(35 \pm 8 \mathrm{~mm})$, together with a clear $\mathrm{pH}$ maximum near the OPD and deeper $\mathrm{pH}$ minimum $(\Delta \mathrm{pH}=2.1 \pm 0.7)$. The presence of cable bacteria was additionally confirmed by FISH (Fig. 5, top row). In November 2015, 5 out of the 10 locations showed the e-SOx geochemical fingerprint. In these
5 locations, the suboxic zone was narrower $(6.8 \pm 1.4 \mathrm{~mm})$ and the acidification of the suboxic zone was less pronounced $(\Delta \mathrm{pH}=1.3 \pm 0.5)$ compared to March. Our data, hence, demonstrate that cable bacteria are widespread in hypoxia impacted sediments in Lake Grevelingen, particularly in spring. 
Located just south of Lake Grevelingen, the Eastern Scheldt (2) is cut off from river inputs by dams, but maintains an open connection to the North Sea through a storm surge barrier. The intertidal area of the Eastern Scheldt is composed of four main habitats: bioturbated sand flats, mud flats, salt marshes and bivalve reefs composed of mussels and/or oysters. A survey was conducted over the course of 2 days in November 2015, investigating the presence and activity of cable bacteria in these four habitats.

Five intertidal sites were investigated and, at each site, one or more locations were sampled by manual coring at low tide. Sediment cores were taken from a total of eight locations distributed over these five sites, and all cores were examined by microsensor profiling within $24 \mathrm{~h}$ after collection. In six locations (including one mud flat, three salt marshes and two bivalve reef habitats), the distinct geochemical fingerprint of e-SOx was present with a suboxic zone of 3-25 mm and a $\Delta \mathrm{pH}$ ranging from 0.8 to 2.3 (Fig. 5). A subsample from all cores was examined using light microscopy and SEM, which confirmed the presence of cable bacteria in all six locations as having the e-SOx fingerprint. A representative geochemical profile and SEM image of cable bacteria are given in Fig. 5b and d. Given the relatively low sampling effort, the high percentage of locations with cable bacteria demonstrates that cable bacteria are widely present within the cohesive sediment habitats of the Eastern Scheldt.

The Western Scheldt (3) comprises a third branch of the Rhine-Meuse-Scheldt delta and has a very different biogeochemistry compared to Lake Grevelingen and the Eastern Scheldt. In contrast to the two northern arms, this important shipping route to the harbour of Antwerp has remained a true estuary and connects the Scheldt River to the North Sea. Four intertidal sites were sampled in November 2015 by manually collecting cores at low-tide (eight locations in total; see full details in Table S1). The geochemical profiles showed no indication of cable bacteria activity: no $\mathrm{pH}$ excursions were detected (e.g. no elevated $\mathrm{pH}$ in the oxic zone and no sharp decrease in $\mathrm{pH}$ in the anoxic zone). Ensuing microscopic examination of the sediment by light microscopy and SEM did not reveal any presence of cable bacteria.

\subsubsection{Wadden Sea}

On the barrier island of Texel, a survey was conducted in the Mokbaai bay at the southern tip of the island (one site, five locations sampled) and within the Cocksdorp area in the northern part of the island (three locations sampled in total). All sites are listed in Table 1 (full information on locations in Table S1). The Mokbaai area is a sheltered bay which receives an input of sediment and organic matter from the Wadden Sea. In the bay, current velocities decrease towards land due to the presence of a bivalve reef, which spans nearly the whole inlet of the bay. Moving from offshore to inshore, five distinct habitats are sequentially present: (1) a bivalve reef of mixed mussels and oysters, (2) a mud accumulation area be- hind the reef with little or no burrowing infauna, (3) an intertidal mud flat with high cockle densities (Cerastoderma edule), (4) sand flats dominated by the lugworm Arenicola marina and (5) salt marshes. In July 2014 sediment cores from each of the five habitats were collected (three to five cores per habitat) and analysed within $3 \mathrm{~h}$ of collection in a nearby laboratory (NIOZ - Texel). Cable bacteria activity was detected in at least one core per habitat except for the sand flats. From all the cores taken at the bivalve reef $(n=4)$, cable bacteria activity was detected in two cores $(\Delta \mathrm{pH}=1.1-1.3)$. The geochemical fingerprint of e-SOx was also present in two out of three cores collected within the mud accumulation area behind the reef $(\Delta \mathrm{pH}=0.95-1.2)$ and in all the cores $(n=3)$ sampled above the cockle bed, which showed high $\mathrm{pH}$ excursions $(\Delta \mathrm{pH}=1.7 \pm 0.3)$. In contrast, the geochemical fingerprint of e-SOx was absent in all cores taken from the sandy bioturbated area $(n=4)$. The presence of cable bacteria in this sandy sediment was further investigated with light microscopy, but no filamentous bacteria were encountered.

In the Cocksdorp area, an extensive bivalve reef (mussels and oysters) stretches out parallel to the coastline. Three sites were sampled in July 2014: one site was in a reef section dominated by oysters (Crassotrea gigas), a second site was situated near a reef section dominated by mussels (Mytilus edulis) and a third site was located on the intertidal mud flat between the reef and the landside. Cable bacteria were active in both reef sections. Cable bacteria activity was detected in three out of four cores taken at the "oyster site" and in two out of four cores taken at the "mussel site". No cable bacteria activity was measured $(n=3)$ on the intertidal mud flat. The absence of cable bacteria at this site might be explained by the large cover of decaying macroalgae on the mud flat (approx. $60 \%$ ), which was present at the time of sampling and which could essentially asphyxiate the sediment (cutting off the $\mathrm{O}_{2}$ supply to cable bacteria).

\subsection{Global distribution}

In addition to the habitats in the southern North Sea area, another five coastal habitats were investigated in widely different geographical locations: Long Island Sound, USA; Yarra River, Australia; Kobbefjord, Greenland; Etang d'Urbino (seagrass bed, France); Sabkhet Arina (salt pan, Tunisia). Given the challenging logistics of in situ sampling, the potential to develop an active cable bacteria population was assessed using laboratory incubations (Table 1). In the first three sites the temporal development of the cable bacteria activity was monitored over time using geochemical profiling (Fig. 6). At the two other sites, the presence and activity of cable bacteria was investigated at one time point with geochemical profiling and SEM imaging (Fig. 7). 


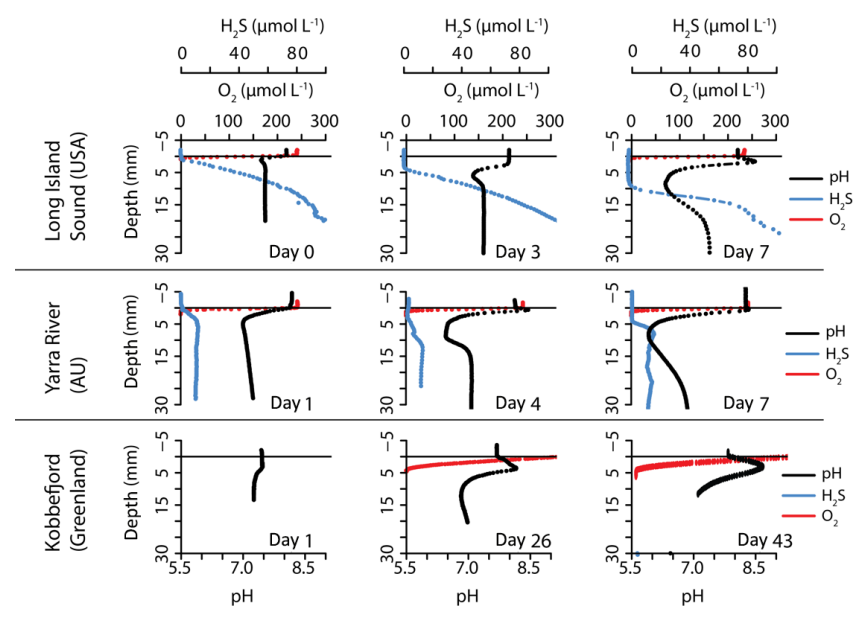

Figure 6. Microsensor depth profiles from laboratory incubation experiments within three widely different climatic regions. Sediments were profiled at regular time intervals during incubation. Top row: sediment from Long Island Sound (New York, USA) showed the characteristic $\mathrm{pH}$ excursions of e-SOx after 7 days of incubation. Middle row: sediment from the Yarra River (Melbourne, Australia) showed cable bacteria activity after 4 days of incubation. Bottom row: sediment from Kobbefjord (Nuuk, Greenland) showed the $\mathrm{pH}$ fingerprint of cable bacteria activity after 26 days of incubation.

\subsubsection{Depositional basin, Long Island Sound, USA}

Long Island Sound (New York, USA) experiences high nutrient loadings and a seasonal stratification of the water column, which leads to a yearly recurring period of oxygen depletion in the bottom waters of the eastern and central parts of the basin (Cuomo et al., 2014). Sediment was collected using a Soutar-style box corer in August 2013 at a site in a depositional area in Port Jefferson harbour (10 m depth, details in Table 1). Sediment cores were subsequently sieved, homogenized and finally incubated at room temperature (20$21^{\circ} \mathrm{C}$ ) in a darkened incubation tank with seawater from the field site (salinity 28). After a period of overnight equilibration, microsensor profiling $\left(\mathrm{pH}, \mathrm{H}_{2} \mathrm{~S}\right.$ and $\mathrm{O}_{2}$ ) was performed daily on triplicate sediment cores to track the development of cable bacteria activity (top row, Fig. 6). Already after 3 days of incubation, we observed an acidification of the sediment $(-1.2 \mathrm{pH}$ units vs. overlying water, OLW) near the $\mathrm{SAD}(4.2 \mathrm{~mm})$. The full geochemical signature of e-SOx was present after 7 days of incubation. A pH maximum evolved in the oxic zone of the sediment $(+0.55 \mathrm{pH}$ units vs. OLW), a wide suboxic zone was present $(8 \mathrm{~mm})$ and a $\mathrm{pH}$ minimum $(-1.7 \mathrm{pH}$ units vs. OLW) was located near the SAD.

\subsubsection{Seasonally hypoxic estuary, Yarra River, Australia}

The Yarra River runs through the city of Melbourne and forms an estuary that discharges into Port Philip bay. During dry spells and a low influx of freshwater, a salt wedge

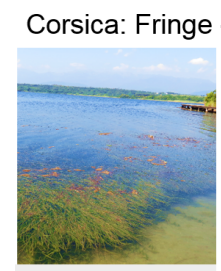

(a) Sampling site

Tunisia: Coastal salt pan

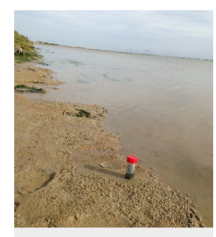

(d) Sampling site

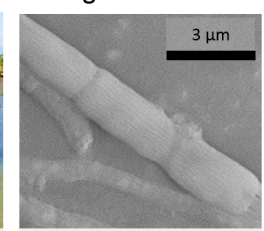

(b) SEM image

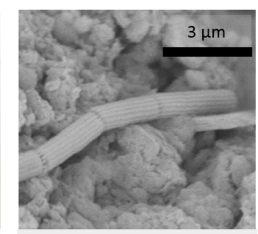

(e) SEM image

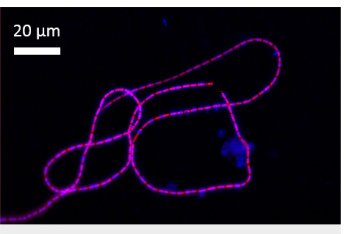

(c) FISH image

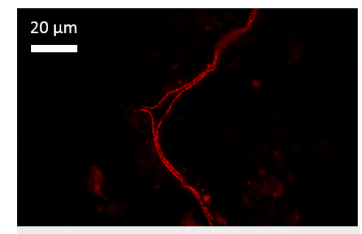

(f) FISH image
Figure 7. Microscopy reveals the presence of cable bacteria in two different habitats in the Mediterranean. (a-c) Sediment near a seagrass bed in the Urbino lagoon (Corsica, France). (d-f) Sediment near the water line of the salt pan Sabkhet Arina (Tunis, Tunisia). Left image: photograph from the sampling sites. Middle image: scanning electron micrographs of cable bacteria filaments with the typical ridge pattern. Right image: Fluorescence in situ hybridization (FISH) images using a DSB706 probe. Full-size SEM images are available in the Supplement (Fig. S2.3-2.4).

forms in the estuary resulting in bottom water oxygen depletion. We examined a site in the Yarra River, referred to as Scotch College, which is known to experience seasonal hypoxia (e.g. Roberts et al., 2012; Robertson et al., 2016). Sediment cores were retrieved in February 2014 using a hand corer and transferred to a nearby laboratory (Water Studies Centre, Monash University, Melbourne). Sediment was sieved and homogenized to exclude shell material and plant debris. Newly repacked cores were reoxygenated and followed up over time (Fig. 6, middle row) to measure the development of cable bacteria activity (temperature $20-25^{\circ} \mathrm{C}$, salinity 18). After 4 days, the distinct $\mathrm{pH}$ profile of e-SOx was present in the sediment: an alkalinization within the oxic zone $(+0.4 \mathrm{pH}$ units vs. OLW) accompanied by an acidification of the deeper sediment $(-1.8 \mathrm{pH}$ units vs. OLW). After 7 days, a suboxic zone developed ( $3 \mathrm{~mm}$ wide) and a lower $\mathrm{pH}$ minimum was measured at the SAD $(-2.3 \mathrm{pH}$ units vs. OLW). Light microscopy confirmed the presence of long, small filamentous bacteria in the cores after 3 days of incubation. Cable bacteria presence was confirmed with sediment samples taken at the end of the incubation using FISH staining.

\subsubsection{Subpolar fjord sediment, Kobbefjord, Greenland}

Kobbefjord is a fjord near the Arctic Circle in Greenland, which is composed of a series of basins and sills. The bottom water is oxygenated year-round $\left(>200 \mu \mathrm{mol} \mathrm{L} \mathrm{L}^{-1}\right)$ and has a low temperature range $\left(-0.5-3{ }^{\circ} \mathrm{C}\right)$ (Sørensen et al., 2015). 
A site at $110 \mathrm{~m}$ depth was sampled using a Kajak gravity corer (diameter $5.3 \mathrm{~cm}$ ). Sediment cores were incubated in the laboratory at bottom water temperature $\left(0^{\circ} \mathrm{C}\right)$. Sediment cores were asphyxiated for 3 weeks and subsequently oxygenated and tracked over 98 days with $\mathrm{pH}$ and $\mathrm{O}_{2}$ microsensor profiling (Fig. 6, bottom row). The distinctive $\mathrm{pH}$ profile of e-SOx was visible after 26 days, with a clear $\mathrm{pH}$ peak $(0.7 \mathrm{pH}$ unit vs. OLW) and a distinct acidification deeper down into the sediment. The cable bacteria community remained active for a long time in the sediment cores, even 98 days after the start of the incubation.

\subsubsection{Seagrass bed, Corsica, France}

Muddy sediment was collected on 31 August 2015 from the fringe of a seagrass bed within the Urbino coastal lagoon in eastern Corsica, France (Fig. 7a, details in Tables 1 and S1). The coastal lagoon has a high salinity $(\sim 40$ at the time of sampling, typically 30-38; Fernandez et al., 2006). The sediment was kept in oxygenated water in a container until it returns to the home laboratory in the Netherlands. There the samples were sieved and transferred to plastic core liners (diameter $3.6 \mathrm{~cm}$ ) and incubated for 24 days in oxygenated water bath. The geochemical measurements (data not shown) from the seagrass bed sediments showed all the characteristics of an electroactive sediment, with the characteristic $\mathrm{pH}$ excursions $(\Delta \mathrm{pH}=1.7)$ and the establishment of a suboxic zone $(6.2 \mathrm{~mm})$. Subsequently, a subsample was visualized with SEM and FISH staining. Under the SEM, filamentous bacteria with longitudinal ridges were present (Fig. 7b) and the FISH-staining procedure revealed cable bacteria with a diameter ranging from $0.7-3 \mu \mathrm{m}$ (Fig. 7c).

\subsubsection{Coastal salt pan, Sabkhet Arina, Tunis, Tunisia}

Sediment was collected on 24 April 2015 from the border of a salt pan near Tunis, Sabkhet Arina (details in Tables 1 and S1), when the pan was inundated. The salt pans (sabkhas) in Tunisia have a highly variable salinity depending on the balance between precipitation and freshwater discharge from land vs. the evaporation of the water within the salt pan. Sediment was carefully collected in a screw-top vial (Fig. 7d) and incubated in oxygenated seawater at the home laboratory in the Netherlands. After 34 days the $\mathrm{pH}$ depth profile was measured in the core, which showed a decrease in the suboxic zone $(\Delta \mathrm{pH}=1.2)$. However, due to the lack of $\mathrm{H}_{2} \mathrm{~S}$ measurement or the distinctive $\mathrm{pH}$ peak in the top millimetres, the activity of cable bacteria in this core was not sufficiently proven (data not shown). Nonetheless, the presence of cable bacteria was found by microscopy. First, a subsample of the sediment under the SEM showed long filamentous bacteria with distinctive ridges on the outer cells with a diameter between $1-2 \mu \mathrm{m}$. Secondly, long filamentous bacteria with 1-2 $\mu \mathrm{m}$ diameters were observed during FISH analysis.

\section{Discussion}

\subsection{Cable bacteria: global distribution and habitats}

Ever since the geochemical signature of cable bacteria was first discovered in 2010 in a laboratory induction experiment (Nielsen et al., 2010), more and more evidence that cable bacteria could be important players in the natural elemental cycling of coastal marine sediments has accumulated (Malkin et al., 2014; Nielsen and Risgaard-Petersen, 2015). When cable bacteria are present and active in a given sediment environment, they exert a large impact on the geochemical cycling due to their strong impact on the $\mathrm{pH}$ depth profile (Risgaard-Petersen et al., 2012; Rao et al., 2016b). Additionally, the share of e-SOx in the total oxygen uptake of the sediment in laboratory incubations can be up to $80 \%$ (Vasquez-Cardenas et al., 2015), while field measurements have reported a contribution to the oxygen uptake of up to $34 \%$ (Malkin et al., 2014). Figure 8 provides a global overview of cable bacteria presence and activity, summarizing the new observations presented in this study together with previously reported data from the literature (including gene archive data with a $>97 \%$ similarity to cable bacteria and published geochemical profiles with an e-SOx signature that were not interpreted as such at the time of publication). In the following paragraphs, we provide a short discussion of the different locations and habitats that harbour cable bacteria. Cable bacteria are active in a wide range of coastal sediments, both subtidal as well as intertidal. The coastal habitats where e-SOx activity has now been documented include mud flats, fjord sediments, bivalve reefs, salt marshes, seagrass beds, mangroves, salt flats and seasonally hypoxic sediments (Fig. 8). These environments are all characterized by the accumulation of fine-grained sediments with a relatively high organic carbon content (Table 2); hence they appear to fit the typical e-SOx site as originally proposed in Malkin et al. (2014): (1) the electron donor (sulfide) is available in large quantities/concentrations through high rates of sulfate reduction, (2) an oxygenated overlying water column supplies a favourable electron acceptor (oxygen) by diffusion into the surface layer of the sediment, and (3) sediment fauna is largely absent so that bioturbation pressure is low and the filament network is not disrupted by mechanical disturbance (new observations do find cable bacteria in bioturbated sites; see discussion in Sect. 4.3).

\subsubsection{Mud accumulation sites}

Mud flats form the archetypical example of coastal sites with high rates of sulfate reduction; hence substantial amounts of free sulfide are released into the porewater. This makes them a favourable habitat for cable bacteria. Previously, the presence and activity of cable bacteria was already demonstrated in a subtidal mud flat off the Belgian coast (Malkin et al., 2014; van de Velde et al., 2016). This site has permanently 
Table 2. Sediment characteristics for field sites with cable bacteria activity.

\begin{tabular}{llrrrl}
\hline Site name & Location & porosity & $\begin{array}{r}\text { Org. C. } \\
\text { content }(\%)\end{array}$ & $\begin{array}{r}\text { Median } \\
\text { Grainsize }(\mu \mathrm{m})\end{array}$ & Reference \\
\hline Mokbaai & & 0.78 & 2.0 & 38 & This study \\
Cocksdorp & & 0.54 & 0.5 & 102 & This study \\
Eastern Scheldt & Rattekaai & 0.76 & 2.0 & 40 & This study \\
Lake Grevelingen & Den Osse & 0.89 & 3.1 & 16 & This study \\
Long Island Sound & Port Jefferson & 0.82 & n.d. & $<63$ & This study; Breslin et al. (1999) \\
Kobbefjord & & 0.79 & 4.2 & n.d. & Sørensen et al. (2015) \\
Yarra & Scotch College & 0.83 & n.d. & $<63$ & This study; Ellaway et al. (1982) \\
\hline
\end{tabular}

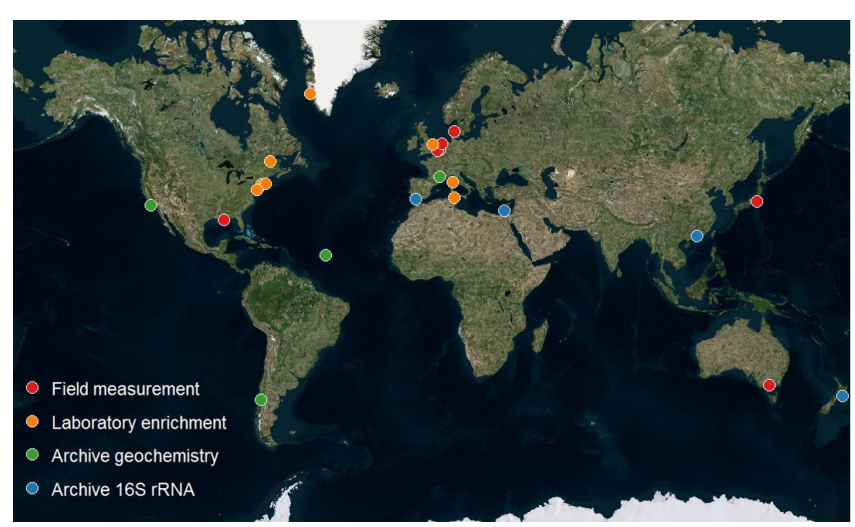

Figure 8. Global distribution of cable bacteria activity and/or presence in marine sediments. The colours of the markers represent the screening method that was used to detect cable bacteria presence or activity. Red markers: direct field observation of cable bacteria activity. Orange markers: cable bacteria activity demonstrated after a laboratory induction experiment. Green markers: published geochemical profiles with an e-SOx signature, but which were not interpreted as such at the time of publication. Blue markers: sites with reported $16 \mathrm{~S}$ rRNA sequences that have a $>97 \%$ similarity to cable bacteria.

oxygenated overlying water and low levels of bioturbation, thus fitting the typical e-SOx site of Malkin et al. (2014) year round. In this study, we show that cable bacteria are also active in intertidal mud flats (see Table 1; Mokbaai and Cocksdorp), where oxygen is supplied from the air through exposure of the sediment at low tide. Additionally, the observation that cable bacteria are potentially active within the deeper basin of Kobbefjord (Fig. 6; Table 1) also fits the idea of cable bacteria being widely present in cohesive sediments. Fjords like Kobbefjord typically show an accumulation of fine-grained sediments, which is due to the focusing of glacially derived material in the deeper basins of the fjords (Sørensen et al., 2015).

\subsubsection{Bivalve reefs}

Recently, it has been shown that cable bacteria proliferate in organic rich sediments that accumulate within mussel and oyster reefs in the Wadden Sea (Malkin et al., 2016). Here, we present field observations of cable bacteria activity at two other bivalve reef sites and one cockle bed in the Wadden Sea (Eastern Scheldt and Mokbaai, Table 1 and Fig. 4), which suggest that cable bacteria are indeed prominently present in these bivalve reefs and beds. By increasing bed roughness and reducing local current velocity, as well as by depositing large quantities of fine particles as pseudofaeces, bivalve reefs show strongly enhanced accumulation of sediment, which is enriched in organics and fine particles (Bergfeld, 1999; van der Zee et al., 2012). Malkin et al. (2017) advanced an intriguing two-way ecological interaction between the bivalves and the cable bacteria, which could be beneficial to both. Through biodeposition of organic rich sediment, the bivalves stimulate sulfate reduction and hence the growth of cable bacteria by increasing the supply of sulfide. On the other hand, the cable bacteria remove the sulfide within the top layer of the sediment and thus detoxify the sediment from free sulfide, which is toxic to the bivalves (and other fauna). A similar two-way interaction could also be occurring in the cockle bed (Mokbaai, Table 1). The cockles are actively filtering seston from the overlying water and, in this way, they also enrich the surface sediment with organic matter and stimulate local sulfide production through sulfate reduction (Widdows and Navarro, 2007). However, unlike the sediment patches within oyster and mussel reefs, which show little bioturbation (Malkin et al., 2017), cockles are known to induce a fair amount of particle mixing (Ciutat et al., 2006). In this sense, the observation of cable bacteria activity in the cockle bed is remarkable and does not fit the low-bioturbation criterion as proposed by Malkin et al. (2014) - see further discussion in Sect. 4.3.

\subsubsection{Salt marshes, seagrass beds and mangroves}

Cable bacteria seem to be widely present in salt marshes. The first report of cable bacteria activity under natural conditions included a salt marsh in the Rhine-Meuse-Scheldt delta of the Netherlands (Malkin et al., 2014). More specifically, Malkin et al. (2014) sampled a mud accumulating creek bed in the salt marsh. These creeks receive large amounts of plant debris, and this constant supply of fresh organic matter pro- 
motes sulfate reduction in the sediment, thus increasing the levels of free sulfide in the porewater. Recent laboratory induction experiments reveal cable bacteria populations in sediments from creek beds and salt marsh ponds in Canada and the USA (Larsen et al., 2015; Rao et al., 2016a). Our study here confirms that cable bacteria are widely active in the unvegetated areas of salt marshes, with new observations of e-SOx in salt marshes of the Dutch delta (Eastern Scheldt, 3 sites, Table 1 and Fig. 4) and the Wadden Sea (Mokbaai, 1 site, Table 1).

Similar to salt marshes, sediments near seagrass beds and mangrove trees receive large amounts of plant debris. Due to wave attenuation by the seagrass bed or the root system of the mangrove trees, plant debris and organic matter accumulates. Cable bacteria are present and active in both these habitats. Burdorf et al. (2016) demonstrated in situ activity of cable bacteria in a temperate mangrove in Australia, while rRNA archives from Liang et al. (2006) point towards the presence of cable bacteria in tropical mangroves in China. In this study, we provide the first report of cable bacteria activity in seagrass beds: a laboratory enrichment of the sediment from the fringe of a Mediterranean seagrass bed (Étang d'Urbino, Corsica) developed an active cable bacteria population (Table 1, Fig. 7). Cable bacteria could potentially play an important role in minimizing the sulfide concentrations that can harm the rhizome system of seagrasses. Although most marine plants have a defensive mechanism in their root system (transporting oxygen through the roots to oxidize sulfide to the harmless sulfate), under certain conditions, the sedimentary production of sulfide can outpace these defences (van der Heide et al., 2012). Note however, that our observations are from the fringe or unvegetated patches within seagrass beds or mangroves, as microsensor profiling near the root-system was avoided due to the high likelihood of sensor breakage. Hence, the question whether cable bacteria are active directly next to the root system of marine plants, where they might improve the conditions in the sediments for these marine plants, remains open.

\subsubsection{Seasonally hypoxic coastal systems}

Seitaj et al. (2015) observed that the occurrence of cable bacteria exhibits a seasonal pattern in the sediments of the seasonally hypoxic Lake Grevelingen, a coastal reservoir in the Netherlands. A multi-year study at one site showed that cable bacteria are abundant in the sediment in winter and spring, while Beggiatoacaea become dominant in the autumn after a period of summer hypoxia. Our investigations here show that cable bacteria activity is present throughout Lake Grevelingen in deeper sediments ( $>12 \mathrm{~m}$ water depth), thus revealing that cable bacteria activity occurs across the whole basin (Table 1 and Fig. 4). When present at high densities, cable bacteria control sedimentary sulfur oxidation, and by imposing acidic conditions in the suboxic zone, they induce the dissolution of the iron sulfides (FeS) in this layer. The mo- bilized iron resulting from $\mathrm{FeS}$ dissolution diffuses upwards and causes the formation of a layer of iron (hydr)oxides in the oxic zone (Seitaj et al., 2015). In summer, this large pool of iron oxides acts as a firewall against the release of sulfide from the sediment to the water column, thus avoiding or delaying a detrimental environmental condition referred to as "euxinia". Overall, cable bacteria were shown to strongly influence the seasonal biogeochemical cycling in Lake Grevelingen through the regulation of the phosphorus cycle (SuluGambari et al., 2016a), manganese cycle (Sulu-Gambari et al., 2016b) and iron cycle (Seitaj et al., 2015).

Cable bacteria activity might have a similar impact on other seasonally hypoxic systems. Here, we demonstrate the rapid development of the e-SOx signal (e.g. less than 7 days) in another seasonally hypoxic system, the Yarra River estuary (Australia). In addition, Sayama (2011) already reported cable bacteria activity in the seasonally hypoxic Tokyo Bay (Japan), while a $\mathrm{pH}$ profile from a depth of $900 \mathrm{~m}$ within the Santa Monica basin (USA) also indicates e-SOx activity (Reimers et al., 1996). Intriguingly, the Santa Monica basin is an anoxic basin with occasional oxygen inflows, and the $\mathrm{pH}$ profile was recorded under low oxygen $\left(8.2 \mu \mathrm{mol} \mathrm{L}^{-1}\right.$ $\mathrm{O}_{2}$ ) and low $\mathrm{pH}$ conditions ( $\mathrm{pH} \sim 7.5$ in the bottom water). The $\mathrm{pH}$ excursions recorded within the Santa Monica basin ( $\Delta \mathrm{pH} \sim 0.4)$ was lower than most sites reported here, which could be due to the acidification of the bottom water (Jahnke, 1990) that modulates the $\mathrm{pH}$ fingerprint of e-SOx. Hence, sites with bottom waters in equilibrium with atmospheric $\mathrm{O}_{2}$ and $\mathrm{CO}_{2}$ could be poised to produce larger $\mathrm{pH}$ excursions than permanent or seasonally hypoxic basins.

Together these data indicate that cable bacteria seem to be particularly prevalent in these environments (Table 1 and Fig. 6). This widespread presence of cable bacteria in seasonally hypoxic systems is not surprising since perturbation induced by seasonal oxygen depletion resembles that of the sediment incubation technique that is used to grow cable bacteria in the laboratory. In these sediment incubations, the infauna is removed from the system and sulfide is allowed to accumulate in the porewater, either by asphyxiation or by thoroughly mixing the sediment (hence mixing oxygenated sediment layers downwards into the bulk anoxic sediment). Such a "reset" of the sediment biogeochemistry apparently favours cable bacteria growth. The seasonal development of hypoxia in coastal bottom waters induces a similar reset of the sediment geochemistry: the hypoxia kills most bioturbating fauna and stimulates benthic processes that produce sulfide. When the bottom waters become oxygenated again, the sediment depth profiles of oxygen and sulfide overlap, which provides ideal starting conditions for the growth of cable bacteria (Schauer et al., 2014). The subsequent development of e-SOx can be rapid. In sediments of the Yarra River site, the distinctive e-SOx $\mathrm{pH}$ signal developed in less than a week after the sediment was exposed to oxygen. The occurrence of coastal hypoxia is on the rise due to an increased anthropogenic input of nutrients into the coastal zone in com- 
bination with climate change (Diaz and Rosenberg, 2008). An improved understanding of the distribution and seasonality of cable bacteria in relation to seasonal hypoxia is hence needed.

\subsubsection{Deep-sea environments}

Coastal sites have received a large part of the sampling effort in the search for cable bacteria, as they provide easy access for sampling. Dedicated studies on cable bacteria activity in deeper environments are still largely lacking. Gene archives, however, suggest the presence of cable bacteria in the deep sea: 16S rRNA sequences similar to cable bacteria have been collected from sediments in the Nile deep-sea fan (Grünke et al., 2011) and at a cold seep off New Zealand (Baco et al., 2010). Geochemical data also hint at the potential activity of cable bacteria in deeper environments, as field recordings of $\mathrm{O}_{2}$ and $\mathrm{H}_{2} \mathrm{~S}$ in sediments from the Mid-Atlantic Ridge imply potential cable bacteria activity at $>3000 \mathrm{~m}$ depth (Schauer et al., 2011). Finally, observations of large filamentous bacteria belonging to the Desulfobulbaceae group have been reported on the surface of inactive sulfide chimneys in the southern Mariana Trough at $2810 \mathrm{~m}$ depth (Kato and Yamagishi, 2016), but it has yet to be determined whether these bacteria also display electrogenic activity. Overall, the distribution of cable bacteria within deep-sea sediments is still largely unknown. Yet, given the reduced organic matter input, the deep oxygen penetration of the surface sediments in the abyssal plains and the absence of sulfate reduction, the vast ambient sediments of the deep sea seem an unlikely habitat for cable bacteria. Based on the scarce evidence that is currently available, it appears that cable bacteria are restricted to localized hotspots, where sulfide is in sufficient supply, such as deep-sea fans, hot vents and cold seeps.

\subsubsection{Non-marine environments}

Recent studies show that e-SOx is not limited to the marine realm, but that cable bacteria can also be active in freshwater environments. The presence and activity of cable bacteria was recently demonstrated in the surface sediment of a freshwater stream in Denmark (Risgaard-Petersen et al., 2015), and preliminary evidence suggests that cable bacteria might also be present and active within the plume fringe of a hydrocarbon-contaminated aquifer in Germany (Müller et al., 2016).

\subsection{Environmental controls on e-SOx}

Given the observed occurrence of cable bacteria activity as discussed above, the question then arises as to what the constraints on the ecological niche of cable bacteria are. In the next sections, we systematically discuss what is known about the environmental controls on the distribution of e-SOx in the seafloor.

\subsubsection{Electron donor availability}

Microorganisms need suitable electron donors to ensure that their energy supply sustains their metabolism and, therefore, sulfide availability could be a key factor. A majority of the reported sites with abundant cable bacteria activity are indeed situated in productive areas with a high input of organic matter, which sustain high sulfate reduction rates and hence high rates of sulfide production (like salt marshes, bivalve reefs, mangroves and seasonally hypoxic basins). The specific pattern of cable bacteria activity that we observed within the Rhine-Meuse-Scheldt delta further supports the idea that sulfide availability could be a crucial constraint. The Rhine-Meuse-Scheldt is a former interconnected estuary, where the construction of dams has led to large differences in the biogeochemistry between the arms of the estuary. The most southern arm (Western Scheldt) has remained a true estuary with freshwater inflow, while the basin just north (Eastern Scheldt) has been cut off from riverine input. The riverine input of iron (derived from terrestrial weathering) combined with high intensity of bioturbation favours dissimilatory iron production in the Western Scheldt. Accordingly, cohesive sediments in the Western Scheldt are typically more ferruginous compared to muddy deposits within the Eastern Scheldt, which tend to have higher rates of sulfate reduction. This geochemical difference is reflected in the presence of cable bacteria. Our survey in November 2015 showed the presence of e-SOx in $>80 \%$ of the sampled (muddy) sediments of the Eastern Scheldt and no presence of e-SOx in the sampled (muddy) sediments of the Western Scheldt (data not shown). Even though this sampling does not completely exclude the presence of cable bacteria in the Western Scheldt, it does show that cable bacteria thrive better in the sulfiderich sediments of the Eastern Scheldt. Note that high sulfide availability does not necessarily require high $\Sigma \mathrm{H}_{2} \mathrm{~S}$ concentrations in the porewater (i.e. one needs a high production rate, not a high stock). Cable bacteria have been observed to thrive in sediments with low concentrations of free sulfide in the porewater $(<5 \mu \mathrm{M}$ in a freshwater stream, Denmark (Risgaard-Petersen et al., 2015) and $<10 \mu \mathrm{M}$ at a coastal site, St130, Belgium (van de Velde et al., 2016). At those sites, a cryptic sulfur cycle is thought to be active: sulfide is produced through sulfate reduction and iron-sulfide dissolution (enhanced by the acidification of the suboxic zone by e-SOx), and this sulfide is immediately consumed through$\mathrm{SO}_{x}$, which then leads to a low concentration of free sulfide in the porewater.

\subsubsection{Electron acceptor availability}

Microorganisms also need access to electron acceptors to sustain their respiratory metabolism. Cable bacteria use either oxygen or nitrate as the terminal electron acceptor (Marzocchi et al., 2014). The availability of $\mathrm{O}_{2}$ was high (>70\% air saturation in the overlying water) at all the field sites 
where cable bacteria activity was detected in this study. Furthermore, in seasonally hypoxic sites, the cable bacteria are present in winter and spring when the overlying water is oxygenated, and they disappear in summer when hypoxia develops (Seitaj et al., 2015), thus confirming the importance of oxygen availability. The exact threshold level of $\mathrm{O}_{2}$ in the overlying water above which cable bacteria can survive and grow, is currently not known, however, and needs further study. Nevertheless, the presence of cable bacteria in intertidal areas does indicate that cable bacteria are capable of dealing with varying oxygen pressures. Diurnal fluctuations due to photosynthesis by microphytobenthos can drastically change the $\mathrm{O}_{2}$ concentrations in the top layer of the sediment, thus leading to a dynamic repositioning of the OPD. To retain access to $\mathrm{O}_{2}$, this requires that cable bacterial filaments follow the rhythms that are imposed on the oxygen availability in the sediment. A study by Malkin and Meysman (2015) showed that cable bacteria quickly responded to a reduction of the OPD when sediment was placed in the dark and photosynthesis by microphytobenthos ceased. To explain this response, the authors hypothesized that cable bacteria are able to migrate towards the oxygen and re-orient themselves in the sediment. Recent microscopical observations of sediments confirm this migration hypothesis (Bjerg et al., 2016).

\subsubsection{Temperature and salinity conditions}

Cable bacteria can apparently tolerate a wide range of temperature conditions. Their geographical distribution does not seem to be limited by temperature: a $0^{\circ} \mathrm{C}$ incubation in Greenland and a $25^{\circ} \mathrm{C}$ incubation in Australia both resulted in the development of an active cable bacteria population. Furthermore, the field observation of cable bacteria in mangrove sediment in southern Australia in the summer suggests that cable bacteria can thrive at even higher temperatures. An even wider tolerance range is observed with respect to the salinity: e-SOx has been reported in freshwater sediments (Risgaard-Petersen et al., 2015), brackish sediment (Yarra River, Australia; this study), marine sediments (the majority of field observations up to present) and a hypersaline environment (Sabkhet Arina salt pan, Tunisia, salinity 40; this study).

\subsection{Biotic controls on cable bacteria distribution: bioturbation}

Bioturbation refers to the reworking of the surface sediment by infauna (Meysman et al., 2006). Bioturbating fauna have been hypothesized to be a main controlling factor in the occurrence of cable bacteria (i.e. Pfeffer et al., 2012; Malkin et al., 2014). As cable bacteria filaments span the sediment over several centimetres, this network could be mechanically damaged by burrowing organisms, thus leading to the collapse of the e-SOx activity. The laboratory mimic of this process, performed by pulling a thin wire through the suboxic zone, indeed leads to an immediate collapse of the distinctive $\mathrm{pH}$ maximum in the top layer of the sediment (Pfeffer et al., 2012; Vasquez-Cardenas et al., 2015). Bioturbation also stimulates the cycling of iron in the sediment, thus favouring dissimilatory iron reduction over sulfate reduction (Canfield et al., 1993). Hence, bioturbation could impede cable bacteria development in a second way by reducing the production rate of sulfide. Because of this, it has been previously suggested that bioturbation exerts restrictive controls on the natural distribution of e-SOx in the seafloor (Malkin et al., 2014).

However, this idea may need some reconsideration. Recent field observations of cable bacteria in bioturbated mangrove areas (Burdorf et al., 2016) and cockle beds (this study), suggest that e-SOx and bioturbation are not mutually exclusive. To more closely examine the relationship between bioturbation and cable bacteria activity, we installed six mesocosms just outside our laboratory facility (NIOZ Yerseke, the Netherlands). Three-quarters of each mesocosm (l: $0.92 \mathrm{~m} \times \mathrm{w}: 1.12 \mathrm{~m} \times \mathrm{h}: 0.63 \mathrm{~m}$, volume: $650 \mathrm{~L}$ ) was filled with defaunated sediment retrieved from a bioturbated sand flat within the Eastern Scheldt (Oude Bieten Haven: $51^{\circ} 26^{\prime} 52^{\prime \prime} \mathrm{N} ; 04^{\circ} 05^{\prime} 47^{\prime \prime} \mathrm{E}$ ). To half of the mesocosms, a population of lugworms (Arenicola marina) was added $(\sim 50$ 60 individuals $\mathrm{m}^{-2}$ ), while the other mesocosms remained devoid of large infauna. Triplicate cores were sampled from each mesocosm in August 2014 and cable bacteria activity was detected in all six mesocosms (Fig. 9). The depth of the $\mathrm{pH}$ minimum was located at approximately the same depth $( \pm 15 \mathrm{~mm})$ in both treatments, which indicates that eSOx was present in the top $15 \mathrm{~mm}$ of the sediment. Yet, the distinctive $\mathrm{pH}$ excursions were larger in the non-bioturbated mesocosms compared to the bioturbated treatment (Fig. 9). The suboxic zone in the bioturbated tanks was significantly larger than in the non-bioturbated tanks, which was probably the result of the ventilation of the porewater by A. marina. These results confirm that cable bacteria are active in bioturbated sediments.

Bioturbation is a concept that covers a diverse group of infauna, which display a variety of sediment reworking activities (e.g. burrowing, moving, feeding). Accordingly, in a bioturbated sediment, different patches will be disturbed with a different frequency and intensity. This heterogeneity with which the sediment is reworked, combined with the fast growth of cable bacteria, can be the key to the observed coexistence of cable bacteria and bioturbating fauna. Laboratory induction experiments (e.g. Fig. 6) have shown that cable bacteria can build up a sizeable activity in less than a week's time. In a bioturbated habitat, if a patch of sediment is not reworked within 1 week, cable bacteria are able to develop. A high bioturbation pressure could thus induce a frequency of patch reworking that is too high for cable bacteria to develop. However, a medium disturbance pressure from bioturbation might even be beneficial to the bacterial growth, as the input of fresh organic material (due to filter feeding 

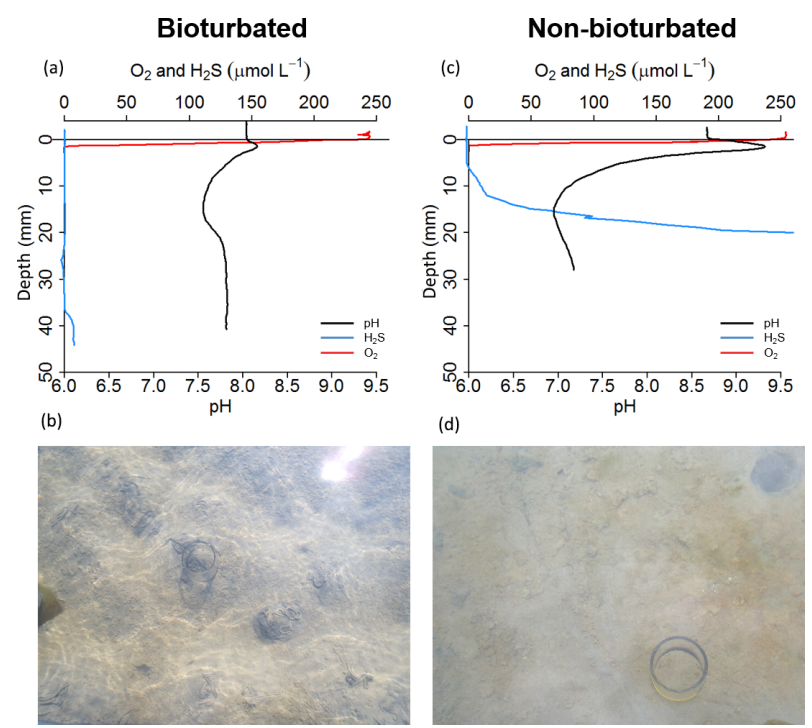

(d)

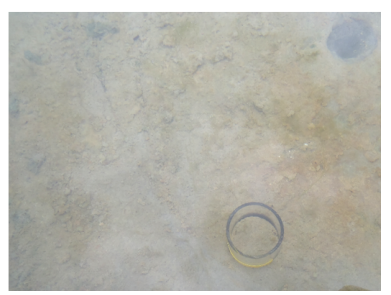

Figure 9. Activity of cable bacteria in mesocosm experiments with two treatments: bioturbated (sediment with the addition of lugworms) and non-bioturbated (control sediment without lugworm addition). (a) Microsensor depth profiles reveal an active cable bacteria population in the bioturbated mesocosm. (b) Surface appearance of the bioturbated sediment showing faecal casts of lugworms. The coring location for microsensor profiling is indicated with the core liner. (c) Geochemical fingerprint in non-bioturbated sediment shows strong cable bacteria activity. (d) Surface appearance of the non-bioturbated sediment with core location for microsensor profiling.

fauna) can stimulate sulfate reduction and thus replenish the sulfide pool available to cable bacteria.

\section{Conclusion}

Cable bacteria are globally present and active in marine sediments. Within coastal areas, cable bacteria are active in a variety of habitats (mud flats, seagrass beds, mangroves, salt marshes, seasonally hypoxic basins) and across all latitudes (from tropical to polar environments). Sampling in a restricted geographical area (the Netherlands) revealed that cable bacteria are found in many locations and at different time points in these coastal habitats. This high ratio of successful detection relative to the sampling effort suggests a widespread occurrence. We contend that similar sampling campaigns in other coastal locations would reveal a similar common occurrence of cable bacteria activity. Previous studies have documented a considerable impact of e-SOx on the elemental cycling (Risgaard-Petersen et al., 2012) and fluxes across the sediment-water interface (Rao et al., 2016b). This combination of a widespread occurrence and a strong local geochemical imprint suggests that cable bacteria could be important in the cycling of carbon, sulfur and other elements in coastal environments. Future research should focus on quantifying the respective share of e-SOx in the natural environment compared to the other types of sulfide oxidation. Seasonality and spatial heterogeneity of cable bacteria are still poorly understood in most habitats. Furthermore, the deep sea remains largely unexplored with respect to the presence and activity of cable bacteria. Based on the scarce evidence that is currently available, cable bacteria seem to be restricted to localized hotspots where sulfide is in sufficient supply (deep-sea fans, hot vents, cold seeps).

This study also provides a better insight into the environmental constraints on the natural distribution of cable bacteria within the seafloor sediments. Cable bacteria are capable of growing in a wide range of temperature and salinity conditions. The ecological niche of cable bacteria appears to be primarily constrained by the availability of suitable electron acceptors $\left(\mathrm{O}_{2} / \mathrm{NO}_{3}\right)$ and the availability of free sulfide as the electron donor (liberated in the porewater through sulfate reduction or through the dissolution of FeS). Sediment disturbance through bioturbation appears to mechanically impede the filament network of cable bacteria, but fast regrowth appears to occur when a sediment patch is left undisturbed for a sufficiently long period. This observation that cable bacteria are also present in bioturbated sediments greatly extends their potential distribution in the present-day seafloor sediments (where most sediments are bioturbated).

\section{Data availability}

The microprofiles generated during this study are available at doi:10.14284/269 (regional field survey) and doi:10.14284/270 (laboratory induction).

\section{The Supplement related to this article is available online at doi:10.5194/bg-14-683-2017-supplement.}

Acknowledgements. We thank all collaborators who hosted and facilitated the numerous field sampling campaigns. For Long Island Sound we thank R. C. Aller, Q. Zhu, J. Soto-Neira, and C. Heilbrun and the crew of the R/V Sea Wolf for their support during sample collection. We are also grateful to J. Soto-Neira, and C. Heilbrun for their help during the laboratory incubations. For the Australian campaigns, we thank P. L. M. Cook, E. K. Robertson and V. Eate for their help and advice during sampling and incubation. For the sampling on Texel, we thank S. Nieuwhof, H. de Stigter and the effort of students (M. Los, D. van Loon, I. Klarenberg and C. van der Weijst). For the sampling on the Lake Grevelingen we thank the crew of the R. V. Navicula. For sampling in Corsica, we thank the Corbara holiday team, while W. Oueslati helpfully assisted in the Tunisian field work.

This research was financially supported by the European Research Foundation (ERC Grant 306933 to FJRM), and the Flanders Research foundation (FWO aspirant grant to L. Meire 
and FWO project G031416N to FJRM), the Department for Education, Church, Culture and Equality (IIKNN Greenland) and the Schure-Beijerinck-Popping Fonds (SBP2013/59.18 to DS), and the Darwin Center for Biogeosciences (DS).

Edited by: G. Herndl

Reviewed by: C. Reimers and two anonymous referees

\section{References}

Baco, A. R., Rowden, A. A., Levin, L. A., Smith, C. R., and Bowden, D. A.: Initial characterization of cold seep faunal communities on the New Zealand Hikurangi margin, Mar. Geol., 272, 251-259, doi:10.1016/j.margeo.2009.06.015, 2010.

Bergfeld, C.: Macrofaunal community pattern in an intertidal sandflat: Effects of organic enrichment via biodeposition by mussel beds, First results, Senckenberg, Maritima, 29, 23-27, doi:10.1007/BF03043114, 1999.

Bjerg, J. T., Damgaard, L. R., Holm, S. A., Schramm, A., and Nielsen, L. P.: Motility of Electric Cable Bacteria, Appl. Environ. Microb., 82, 3816-3821, doi:10.1128/AEM.01038-16, 2016.

Breslin, V. T., Sañudo-Wilhelmy, S. A., and Sanudo-Wilhelmy, S. A.: High Spatial Resolution Sampling of Metals in the Sediment and Water Column in Port Jefferson Harbor, New York, Estuaries, 22, 669-680, doi:10.2307/1353054, 1999.

Burdorf, L. D. W., Hidalgo-Martinez, S., Cook, P. L. M., and Meysman, F. J. R.: Long-distance electron transport by cable bacteria in mangrove sediments, Mar. Ecol.-Prog. Ser., 545, 18, doi:10.3354/meps11635, 2016.

Canfield, D. E., Jørgensen, B. B., Fossing, H., Glud, R., Gundersen, J., Ramsing, N. B., Thamdrup, B., Hansen, J. W., Nielsen, L. P., and Hall, P. O. J.: Pathways of organic carbon oxidation in three continental margin sediments, Mar. Geol., 113, 27-40, doi:10.1016/0025-3227(93)90147-N, 1993.

Ciutat, A., Widdows, J., and Readman, J. W.: Influence of cockle Cerastoderma edule bioturbation and tidal-current cycles on resuspension of sediment and polycyclic aromatic hydrocarbons, Mar. Ecol.-Prog. Ser., 328, 51-64, doi:10.3354/meps328051, 2006.

Cuomo, C., Cochran, J. K., and Turekian, K. K.: Geochemistry of the Long Island Sound Estuary, in Long Island Sound, edited by: Latimer, J. S., Tedesco, M. A., Swanson, R. L., Yarish, C., Stacey, P. E., and Garza, C., 159-201, Springer New York, USA, 2014.

Damgaard, L. R., Risgaard-Petersen, N., and Nielsen, L. P.: Electric potential microelectrode for studies of electrobiogeophysics, J. Geophys. Res.-Biogeo., 119, 1906-1917, doi:10.1002/2014JG002665, 2014.

Diaz, R. J. and Rosenberg, R.: Spreading Dead Zones and Consequences for Marine Ecosystems, Science, 321, 926-929, doi:10.1126/science.1156401, 2008.

Ellaway, M., Hart, B. T., and Beckett, R.: Trace metals in sediments from the Yarra River, Mar. Freshwater Res., 33, 761-778, 1982.

Fernandez, C., Pasqualini, V., Boudouresque, C.-F., Johnson, M., Ferrat, L., Caltagirone, A., and Mouillot, D.: Effect of an exceptional rainfall event on the sea urchin (Paracentrotus lividus) stock and seagrass distribution in a Mediterranean coastal lagoon, Estuar. Coast. Shelf S., 68, 259-270, doi:10.1016/j.ecss.2006.02.020, 2006.
Fofonoff, N. P. and Millard, R. C.: Algorithms for computation of fundamental properties of seawater, UNESCO Tech. Pap. Mar. Sci. Doc. Tech. Unesco Sur Sci. Mer, Unesco, Paris, 1983.

Godinho-Orlandi, M. J. L. and Jones, J. G.: The distribution of some genera of filamentous bacteria in littoral and profundal lake sediments, Microbiology, 123, 91-101, doi:10.1099/00221287-1231-91, 1981.

Grünke, S., Felden, J., Lichtschlag, A., Girnth, A.-C., De Beer, D., Wenzhöfer, F., and Boetius, A.: Niche differentiation among mat-forming, sulfide-oxidizing bacteria at cold seeps of the Nile Deep Sea Fan (Eastern Mediterranean Sea): Niche differentiation among sulfide oxidizers, Geobiology, 9, 330-348, doi:10.1111/j.1472-4669.2011.00281.x, 2011.

Jahnke, R. A.: Early diagenesis and recycling of biogenic debris at the seafloor, Santa Monica Basin, California, J. Mar. Res., 48, 413-436, 1990.

Kato, S. and Yamagishi, A.: A novel large filamentous deltaproteobacterium on hydrothermally inactive sulfide chimneys of the Southern Mariana Trough, Deep-Sea Res. Pt. I, 110, 99-105, doi:10.1016/j.dsr.2015.12.015, 2016.

Larsen, S., Nielsen, L. P., and Schramm, A.: Cable bacteria associated with long-distance electron transport in New England salt marsh sediment, Environ. Microbiol. Rep., 7, 175-179, doi:10.1111/1758-2229.12216, 2015.

Liang, J.-B., Chen, Y.-Q., Lan, C.-Y., Tam, N. F. Y., Zan, Q.-J., and Huang, L.-N.: Recovery of novel bacterial diversity from mangrove sediment, Mar. Biol., 150, 739-747, doi:10.1007/s00227006-0377-2, 2006.

Malkin, S. Y. and Meysman, F. J. R.: Rapid redox Signal transmission by "Cable Bacteria" beneath a photosynthetic biofilm, Appl. Environ. Microb., 81, 948-956, doi:10.1128/AEM.0268214, 2015.

Malkin, S. Y., Rao, A. M., Seitaj, D., Vasquez-Cardenas, D., Zetsche, E.-M., Hidalgo-Martinez, S., Boschker, H. T., and Meysman, F. J.: Natural occurrence of microbial sulphur oxidation by long-range electron transport in the seafloor, ISME J., 8 , 1843-1854, doi:10.1038/ismej.2014.41, 2014.

Malkin, S., Seitaj, D., Burdorf, L., Nieuwhof, S., Hidalgo-Martinez, S., Tramper, A., Geeraert, N., de Stigter, H., and Meysman, F.: Electrogenic sulfide oxidation by cable bacteria in bivalve reef sediments, Front. Mar. Sci., 4, doi:10.3389/fmars.2017.00028, 2017.

Manz, W., Amann, R., Ludwig, W., Wagner, M., and Schleifer, K.H.: Phylogenetic oligodeoxynucleotide probes for the major subclasses of Proteobacteria: problems and solutions, Syst. Appl. Microbiol., 15, 593-600, doi:10.1016/S0723-2020(11)80121-9, 1992.

Marzocchi, U., Trojan, D., Larsen, S., Meyer, R. L., Revsbech, N. P., Schramm, A., Nielsen, L. P., and Risgaard-Petersen, N.: Electric coupling between distant nitrate reduction and sulfide oxidation in marine sediment, ISME J., 8, 1682-1690, doi:10.1038/ismej.2014.19, 2014.

Meysman, F. J. R., Middelburg, J. J., and Heip, C. H. R.: Bioturbation: a fresh look at Darwin's last idea, Trends Ecol. Evol., 21, 688-695, doi:10.1016/j.tree.2006.08.002, 2006.

Meysman, F. J. R., Risgaard-Petersen, N., Malkin, S. Y., and Nielsen, L. P.: The geochemical fingerprint of microbial longdistance electron transport in the seafloor, Geochim. Cosmochim. Ac., 152, 122-142, doi:10.1016/j.gca.2014.12.014, 2015. 
Müller, H., Bosch, J., Griebler, C., Damgaard, L. R., Nielsen, L. P., Lueders, T., and Meckenstock, R. U.: Long-distance electron transfer by cable bacteria in aquifer sediments, ISME J., 10, 2010-2019, doi:10.1038/ismej.2015.250, 2016.

Nielsen, L. P. and Risgaard-Petersen, N.: Rethinking sediment biogeochemistry after the discovery of electric currents, Annu. Rev. Mar. Sci., 7, 425-442, doi:10.1146/annurev-marine-010814$015708,2015$.

Nielsen, L. P., Risgaard-Petersen, N., Fossing, H., Christensen, P. B., and Sayama, M.: Electric currents couple spatially separated biogeochemical processes in marine sediment, Nature, 463 , 1071-1074, doi:10.1038/nature08790, 2010.

Pernthaler, A., Pernthaler, J., and Amann, R.: Fluorescence In Situ Hybridization and Catalyzed Reporter Deposition for the Identification of Marine Bacteria, Appl. Environ. Microb., 68, 30943101, doi:10.1128/AEM.68.6.3094-3101.2002, 2002.

Pernthaler, J., Glockner, F., Schonhuber, W., and Amann, R.: Fluorescence in situ hybridization (FISH) with rRNA-targeted oligonucleotide probes, Method. Microbiol., 30, 207-226, 2001.

Pfeffer, C., Larsen, S., Song, J., Dong, M., Besenbacher, F., Meyer, R. L., Kjeldsen, K. U., Schreiber, L., Gorby, Y. A., El-Naggar, M. Y., Leung, K. M., Schramm, A., RisgaardPetersen, N., and Nielsen, L. P.: Filamentous bacteria transport electrons over centimetre distances, Nature, 491, 218-221, doi:10.1038/nature11586, 2012.

Rao, A. M. F., Risgaard-Petersen, N., and Neumeier, U.: Electrogenic sulfur oxidation in a northern saltmarsh (St. Lawrence Estuary, Canada), Can. J. Microbiol., 62, 530-537, doi:10.1139/cjm-2015-0748, 2016a.

Rao, A. M. F., Malkin, S. Y., Montserrat, F., and Meysman, F. J. R.: Alkalinity production in intertidal sands intensified by lugworm bioirrigation, Estuar. Coast. Shelf S., 148, 36-47, doi:10.1016/j.ecss.2014.06.006, 2014.

Rao, A. M. F., Malkin, S. Y., Hidalgo-Martinez, S., and Meysman, F. J. R.: The impact of electrogenic sulfide oxidation on elemental cycling and solute fluxes in coastal sediment, Geochim. Cosmochim. Ac., 172, 265-286, doi:10.1016/j.gca.2015.09.014, 2016b.

Reimers, C. E., Ruttenberg, K. C., Canfield, D. E., Christiansen, M. B., and Martin, J. B.: Porewater $\mathrm{pH}$ and authigenic phases formed in the uppermost sediments of the Santa Barbara Basin, Geochim. Cosmochim. Ac., 60, 4037-4057, 1996.

Revil, A., Mendonça, C. A., Atekwana, E. A., Kulessa, B., Hubbard, S. S., and Bohlen, K. J.: Understanding biogeobatteries: Where geophysics meets microbiology, J. Geophys. Res.-Biogeo., 115, G00G02, doi:10.1029/2009JG001065, 2010.

Risgaard-Petersen, N., Revil, A., Meister, P., and Nielsen, L. P.: Sulfur, iron-, and calcium cycling associated with natural electric currents running through marine sediment, Geochim. Cosmochim. Ac., 92, 1-13, doi:10.1016/j.gca.2012.05.036, 2012.

Risgaard-Petersen, N., Damgaard, L. R., Revil, A., and Nielsen, L. P.: Mapping electron sources and sinks in a marine biogeobattery, J. Geophys. Res.-Biogeo., 119, 1475-1486, doi:10.1002/2014JG002673, 2014.

Risgaard-Petersen, N., Kristiansen, M., Frederiksen, R. B., Dittmer, A. L., Bjerg, J. T., Trojan, D., Schreiber, L., Damgaard, L. R., Schramm, A., and Nielsen, L. P.: Cable Bacteria in Freshwater Sediments, Appl. Environ. Microb., 81, 6003-6011, doi:10.1128/AEM.01064-15, 2015.
Roberts, K. L., Eate, V. M., Eyre, B. D., Holland, D. P., and Cook, P. L. M.: Hypoxic events stimulate nitrogen recycling in a shallow salt-wedge estuary: The Yarra River Estuary, Australia, Limnol. Oceanogr., 57, 1427-1442, doi:10.4319/lo.2012.57.5.1427, 2012.

Robertson, E. K., Roberts, K. L., Burdorf, L. D. W., Cook, P., and Thamdrup, B.: Dissimilatory nitrate reduction to ammonium coupled to $\mathrm{Fe}(\mathrm{II})$ oxidation in sediments of a periodically hypoxic estuary, Limnol. Oceanogr., 61, 365-381, doi:10.1002/lno.10220, 2016.

Sayama, M.: Seasonal dynamics of sulfide oxidation processes in Tokyo Bay dead zone sediment, Goldschmidt Conference Abstracts, Prague, 2011.

Schauer, R., Røy, H., Augustin, N., Gennerich, H.-H., Peters, M., Wenzhoefer, F., Amann, R., and Meyerdierks, A.: Bacterial sulfur cycling shapes microbial communities in surface sediments of an ultramafic hydrothermal vent field, Environ. Microbiol., 13, 2633-2648, doi:10.1111/j.1462-2920.2011.02530.x, 2011.

Schauer, R., Risgaard-Petersen, N., Kjeldsen, K. U., Tataru Bjerg, J. J., Jørgensen, B. B., Schramm, A., and Nielsen, L. P.: Succession of cable bacteria and electric currents in marine sediment, ISME J., 8, 1314-1322, doi:10.1038/ismej.2013.239, 2014.

Seitaj, D., Schauer, R., Sulu-Gambari, F., Hidalgo-Martinez, S., Malkin, S. Y., Burdorf, L. D. W., Slomp, C. P., and Meysman, F. J. R.: Cable bacteria generate a firewall against euxinia in seasonally hypoxic basins, P. Natl. Acad. Sci. USA, 112, 13278-13283, doi:10.1073/pnas.1510152112, 2015.

Soetaert, K., Petzoldt, T., and Meysman, F.: marelac: Tools for Aquatic Sciences. R package version 2.1, available at: http://cran. r-project.org/web/packages/marelac, 2010.

Sørensen, H., Meire, L., Juul-Pedersen, T., de Stigter, H., Meysman, F., Rysgaard, S., Thamdrup, B., and Glud, R.: Seasonal carbon cycling in a Greenlandic fjord: an integrated pelagic and benthic study, Mar. Ecol.-Prog. Ser., 539, 1-17, doi:10.3354/meps11503, 2015.

Sulu-Gambari, F., Seitaj, D., Meysman, F. J. R., Schauer, R., Polerecky, L., and Slomp, C. P.: Cable Bacteria Control Iron-Phosphorus Dynamics in Sediments of a Coastal Hypoxic Basin, Environ. Sci. Technol., 50, 1227-1233, doi:10.1021/acs.est.5b04369, 2016a.

Sulu-Gambari, F., Seitaj, D., Behrends, T., Banerjee, D., Meysman, F. J. R., and Slomp, C. P.: Impact of cable bacteria on sedimentary iron and manganese dynamics in a seasonallyhypoxic marine basin, Geochim. Cosmochim. Ac., 192, 49-69, doi:10.1016/j.gca.2016.07.028, 2016b.

Trojan, D., Schreiber, L., Bjerg, J. T., Bøggild, A., Yang, T., Kjeldsen, K. U., and Schramm, A.: A taxonomic framework for cable bacteria and proposal of the candidate genera Electrothrix and Electronema, Syst. Appl. Microbiol., 39, 297-306, doi:10.1016/j.syapm.2016.05.006, 2016.

van der Heide, T., Govers, L. L., de Fouw, J., Olff, H., van der Geest, M., van Katwijk, M. M., Piersma, T., van de Koppel, J., Silliman, B. R., Smolders, A. J. P., and van Gils, J. A.: A three-stage symbiosis forms the foundation of seagrass ecosystems, Science, 336, 1432-1434, doi:10.1126/science.1219973, 2012.

van der Zee, E. M., van der Heide, T., Donadi, S., Eklöf, J. S., Eriksson, B. K., Olff, H., van der Veer, H. W., and Piersma, T.: Spatially extended habitat modification by intertidal reef- 
building bivalves has implications for consumer-resource interactions, Ecosystems, 15, 664-673, 2012.

van de Velde, S., Lesven, L., Burdorf, L. D. W., Hidalgo-Martinez, S., Geelhoed, J. S., Van Rijswijk, P., Gao, Y., and Meysman, F. J. R.: The impact of electrogenic sulfur oxidation on the biogeochemistry of coastal sediments: A field study, Geochim. Cosmochim. Ac., 194, 211-232, doi:10.1016/j.gca.2016.08.038, 2016.

Vasquez-Cardenas, D., van de Vossenberg, J., Polerecky, L., Malkin, S. Y., Schauer, R., Hidalgo-Martinez, S., Confurius, V., Middelburg, J. J., Meysman, F. J. R., and Boschker, H. T. S.: Microbial carbon metabolism associated with electrogenic sulphur oxidation in coastal sediments, ISME J., 9, 1966-1978, doi:10.1038/ismej.2015.10, 2015.
Westeijn, L. P. M. J.: Grevelingenmeer: meer kwetsbaar? Een beschrijving van de ecologische ontwikkelingen voor de periode $1999 \mathrm{t} / \mathrm{m}$ 2008-2010 in vergelijking met de periode $1990 \mathrm{t} / \mathrm{m}$ 1998, RWS Waterdienst, Lelystad, 2011.

Widdows, J. and Navarro, J. M.: Influence of current speed on clearance rate, algal cell depletion in the water column and resuspension of biodeposits of cockles (Cerastoderma edule), J. Exp. Mar. Biol. Ecol., 343, 44-51, doi:10.1016/j.jembe.2006.11.011, 2007. 